\title{
Ovjere sekularizacije - aktualnost Mardešićevih istraživanja
}

Stjepan Brebrić*

ks@zg.t-com.hr
UDK: 316:2 Mardešić, Ž.

211.5

Izvorni znanstveni rad / Original scientific paper Primljeno: 6. rujna 2016. Prihvaćeno: 18. listopada 2016.

Znanstvena ovjera sekularizacije u ovome članku je okvirno područje istraživanja religiologijski relevantnih društveno-kulturalnih promjena, s posebnim naglaskom na značenju tih promjena za kršćanstvo i u samome kršćanstvu. Način na koji se promišlja o sekularizaciji pretpostavlja se kao prikladan za uvažavanje višeznačja i složenosti sekularizacijskih procesa u pogledu aktualizacije njihove hermeneutičke valjanosti za novije analize i tumačenja položaja $i$ uloge kršćanstva i religije u suvremenom društvu i svijetu današnjice. Istodobno se nastoji oko aktualizacije relevantnih istraživanja Željka Mardešića, kako u pogledu samoga fenomena sekularizacije, tako i sobzirom na novije usporedive društveno-kulturalne procese u sadašnjosti.

Ključne riječi: sekularizacija, modernitet, ovjera, sociologija religije, teologija, kršćanstvo, religija, vjera, etika, društvo, svijet, sveto.

\footnotetext{
* Dr. sc. Stjepan Brebrić, direktor i gl. urednik, Kršćanska sadašnjost, Marulićev trg 14, HR10000 Zagreb.
} 


\section{Uvod}

U ovome radu, nastalome na temelju zajedničkih promišljanja o sekularizaciji i tzv. »antisekularizacijskoj pobuni« u perspektivi jednako relevantnih i aktualnih Mardešićevih istraživanja problematike ${ }^{1} u$ središtu zanimanja nalazi se temeljna problemska stvarnost - fenomen sekularizacije. Sekularizacija se pri tom tretira u vidu njezine socio-religiologijske i teološke, odnosno crkvene ovjere. U pristupu temi uključeno je prepoznavanje aktualizacijskih potencijala Mardešićevih uvida u problematiku sekularizacije i kršćanstva, primjenjivih u analizi usporedivih i s dotičnom problematikom povezivih procesa u društveno-kulturalnome okruženju današnjice.

Polazeći od vjerojatno temeljnih pogleda Željka Mardešića na problematiku sekularizacijskih (i »antisekularizacijskih«) procesa u Crkvi, društvu i religioznome životu poglavito kršćanskih vjernika današnjice, ${ }^{2}$ važnija pitanja o kojima bi ovdje također valjalo promišljati tiču se percepcije sekularizacije i usporedivih procesa u suvremenosti, s pozornošću prema nekim od teološki relevantnijih implikacija, uočljivih u pokušaju stanovitoga načina razumijevanja i sinkronijskoga tumačenja sadržaja i funkcije svetoga i profanoga, (de) sakralizacije, sekularizacije i sekularizma, laicizacije i laičnosti, pluralizacije i pluralizma, kao i nekih novijih pojava na području društvene i kulturalnoantropološke zbilje, zbog kojih su kršćanski mislioci današnjice suočeni sa sve težim i izazovnijim pitanjima. O svemu tome, međutim, moguće je suvislo raspravljati samo ako se prethodno iznesu i razjasne valjani razlozi za neupitnost sekularizacijskih procesa u novijoj povijesti i ako se pri tom sekularizacija shvati kao složena i višeznačna društveno-kulturalna stvarnost, koja postaje važnim hermeneutičkim ključem za razumijevanje svih onih pojava i stvarnosti, na koje se odnose naprijed nabačena pitanja, a kako se čini, upravo na taj način

${ }^{1}$ Članak je prerađena verzija izlaganja održanog u Zagrebu, 15. ožujka 2016. godine na okruglome stolu prigodom 10. obljetnice smrti Željka Mardešića (1933-2006), na poziv i u organizaciji Kršćanskoga akademskog kruga.

${ }^{2}$ Mardešićeva istraživanja sekularizacije i moderniteta, kao uže i specifične, odnosno šire i općenitije kulturološke stvarnosti, čini se, s obzirom na zastupljenost te problematike u njegovu stvaralačkome opusu, preferiranim područjem zanimanja i naglašenim aspektom socio-religiologijskih analiza. Nezahvalno je u širini i dubini njegove misli isticati jednu temu kao središnju i najvažniju. No, čini se da je najveći dio istraživanja uvelike povezan s problematikom koja bi se pojmovno mogla odrediti kao »kršćanstvo i sekularizacija «. Pri tom se misli na događanja koja su obilježjem suvremenoga kršćanstva, ali i općenito tradicionalnijih oblika religioznosti. U njihovu središtu prepoznaje se fenomen sekularizacije, s kojim su u izravnoj vezi i pojave poput rascvata nove religioznosti i oživljavanja religioznih ostataka prošlosti. Sekularizacijske procese, koje otkriva na trostrukoj razini - društvenoj, crkvenoj i individualnoj - Mardešić istražuje ne samo kao ovjerljivi i stoga dokazivi povijesno-kulturalni fenomen, nego i kao preduvjet za ispravno razumijevanje stvarnoga stanja suvremene religioznosti i duhovnosti općenito, odnosno kršćanstva i kršćanske vjere napose [usp. Ž. MARDEŠIĆ, Kršćanstvo i sekularizacija, Nova prisutnost, 4 (2006) 2, 256-280; J. JUKIĆ, Kršćanstvo i sekularizacija, Diacovensia, 8 (2000) 1, 69-87; Kršćanstvo, sekularizacija $i$ modernitet, u: isti, Rascjep u svetome, Zagreb, 2007, 243-280]. 
u svojoj socio-religiologijskoj obradi sekularizaciju shvaća i Željko Mardešić. O ovjeri sekularizacijskih procesa čini se vrijednim iznova promišljati i zbog uporabe pojma »sekularizacija« u općenitome, a nerijetko i oprečnome značenju, kao i zbog dojma o njegovu postupnome iščezavanju na pojedinim relevantnim područjima aktualnoga znanstvenog diskursa.

Bez obzira što se ovdje naglasak stavlja na temeljnu stvarnost, sekularizacija i antisekularizacija, kao jedinstveno shvaćena tema, poput svake ozbiljne i složene problematike, već u samome određenju preferiranoga pristupa povezuje se s mnogim poteškoćama načelne, teoretske i praktične naravi. Osnovni problem kod ove teme, kada se o njoj želi misliti u skladu s već istraženim i rečenim $^{3}$ - a jednako u pokušaju aktualizacije konkretnoga istraživalačkoga prinosa, nemjerljive vrijednosti po opsežnosti, iscrpnosti, kontinuitetu i dubini, kao što je Mardešićev ${ }^{4}$ - stoji u njezinoj kompleksnosti, širini, ali i u postojanju najrazličitijih razina poimanja, kao i činjeničnoga, ili barem fenomenologijskoga prepoznavanja stvarnosti, o kojoj ovise glavna svojstva relevantnih tematski raspoznatljivih područja i predmeta mišljenja.

Već gotovo sedamdesetak godina ${ }^{5}$ ova se tema u izravnoj problemskoj obradi očituje kao trajno ispreplitanje, podudaranje, razlikovanje, približavanje i

\footnotetext{
${ }^{3}$ Usp. S. TADIĆ, Sekularizacija, antisekularizacija i suvremena revitalizacija religije, Nova prisutnost, 5 (2007) 1, 21-38; isti, Sveto koje to nije. O imanentističkim religijama u suvremenom svijetu, Nova prisutnost, 9 (2011) 2, 409-421; V. MIHALJEVIĆ, Novi religijski pokreti u djelu Željka Mardešića, Nova prisutnost, 6 (2008) 2, 203-224; V. KOVAČEVIĆ, Metamorfoze sekularizacije u modernitetu, Nova prisutnost, 9 (2011) 2, 403-408; P. KUFRIN, Kršćanstvo i sekularizacija u viziji Željka Mardešića, Nova prisutnost, 9 (2011) 2, 487-492.

${ }^{4}$ Od svoje prve knjige Željko Mardešić (pod pseudonimom J. JUKIĆ, Religija u industrijskom društvu, Split, 1973), pa sve do posljednje objavljene (Ž. MARDEŠIĆ, Rascjep u svetome, Zagreb, 2007), kontinuirano promišlja ne samo o sekularizaciji kao temi, nego i pod vidikom sekularizacijske problematike o svim religiologijski relevantnim društvenim i kulturalnim temama predmodernoga, modernoga i postmodernoga svijeta. Najizravnija su i ujedno najviše aktualna takva njegova promišljanja u posljednjim tekstovima, koje je pisao kao redovitu mjesečnu kolumnu u Kršćanskoj obiteljskoj reviji »Kana« od 2002. do 2006. godine. Od prve kolumne, naslovljene "Sekularizacija i rat" (Kana, 357 (2002) 7-8, str. 17) do posljednje, objavljene desetak dana prije autorove smrti (26. lipnja 2006.), čiji je naslov »Sekularizacija i otkriće Istoka« [Kana, 400 (2006) 6, 14], Mardešić niže ukupno 43 promišljanja na temu »Sekularizacija i ...« (...rat; politika; država; modernitet; integrizam; fundamentalizam; globalizacija; tranzicija; ideologija; pluralizam; pamćenje; identitet; katolicizam; obraćenje; demokracija; novi ateizmi; civilno društvo; postmodernitet; mediji; komunizam; teologija; kršćanstvo; sotonizacija; nacionalizam; demokršćanstvo; židovstvo; kolonizacija; civilna religija; integracija; adaptacija; sekularizam; pobuna religija; društveno oslobođenje; prošlost; beznađe; odgovori vjernika; crkveni pokreti; mnogoboštvo i idolatrija; ekumenizam; promijenjeni svijet; (Sekularizacija) Jeruzalema; religijske prilagodbe (sekularizaciji)). Veći dio ovih promišljanja Mardešić je za života uspio obraditi i u znanstveno-istraživalačkoj formi te se takvima nalaze u njegovoj posthumno objavljenoj knjizi [»Ono što sam u Svjetlu Riječi i Kani pisao na popularan način, ovdje pokušavam znanstveno potkrijepiti i stručno obrazložiti« (Mardešić, Rascjep u svetome..., 7)].

${ }^{5}$ Misli se na vrijeme u kojemu sekularizacija postaje jednom od najzastupljenijih općih tema u suvremenoj znanosti, prvenstveno na području sociologije religije. Iako je velik broj sociologa religije koji su zastupanjem teze o sekularizaciji označili ovo razdoblje njezine silne teoretizacije, usporedno s empirijskim sociološkim istraživanjima, za početak prouke sekularizacijskih
} 
udaljavanje mnogih vrsta i podvrsta kategorijalnoga mišljenja, ali i konkretnih načina djelovanja, odnosno postupanja u praktičnim oblicima života, od čega su dvije osnovne teoretska i praktična, ili idejna i iskustvena, koje također $\mathrm{u}$ obzorju ove problematike kao da nerijetko zamjenjuju mjesta te nije uvijek ni dovoljno jasno, s kojom smo od dviju različitih razina suočeni u prepoznavanju jednoga ili drugoga vida nepregledne stvarnosti, iako se ona pobliže opisuje pojavama iskustveno ili empirijski utvrdivih znakova i značenja, odnosno, njihovim daljnjim tumačenjima.

Nakon mnogih teoretizacija i empirijskih istraživanja sekularizacijskih procesa čini se ipak dostatno razvidnim o čemu je u osnovi riječ. Misli se prvenstveno na proces sekularizacije, posvjetovljenja ili desakralizacije kao gubitak institucionalne, društvene i kulturalne relevantnosti religije, odnosno kršćanstva. Taj proces prihvaća se kao znanstveno utvrdivu činjenicu moderne povijesti čovječanstva, iako se ona najradije iskazuje u obliku jedne više ili manje sigurne znanstvene teorije, a slično i na s tim usporednu pojavu antisekularizacijskoga fenomena, opisiva u jednako utvrdivim činjenicama buđenja ili jačanja religioznosti na individualnoj, ali i na društvenoj i kulturalnoj razini, što također omogućuje solidno postavljanje nove, povezane, ali znanstvene teorije koja otkriva i ukazuje na drukčije, zapravo suprotne činjenice onima, o kojima je općenito riječ u sekularizacijskoj teoriji. No, takvo shvaćanje tematike, uporabom rečenih pojmova, naglasak stavlja na dva suprotstavljena religiologijski važna društvena i kulturalna procesa kroz razumijevanje njihove međuodnosnosti i međuovisnosti, pri čemu se drugim pojmom sugerira suprotstavljanje procesu koji izriče prvi pojam, što nije, naravno, znanstveno neutemeljivo, a još je manje misaono neopravdano shvaćanje cjelokupne problematike. Stoga se ovdje, upravo zbog složenosti i višeznačnosti glavnih sastojnica i različitih interpretacija teorije o sekularizaciji, kao i njezine raznolike znanstvene primjene, korisnim čini barem spomenuti mogućnost i drugačijega razumijevanje ove

procesa u modernome društvu na svjetskoj razini najutjecajniji su autori koji objavljuju svoja značajnija djela šezdesetih godina prošloga stoljeća (usp. S. ACQUAVIVA, L’eclissi del sacro nella civiltà industriale, Milano, 1966; B. WYLSON, Religion in Secular Society: Sociological Comment, London, 1966; P. BERGER, Th. LUCKMANN, The Social Construction of Reality: A Treatise in the Sociology of Knowledge, New York, 1966; Th. LUCKMANN, The Invisible Religion. The Transformation of Symbols in Industrial Society, New York, 1967; P. BERGER, The Sacred Conopy: Elements of a Sociological Theory of Religion, New York, 1967; D. MARTIN, The Religious and the Secular. Essays in Secularisation, London, 1969). Kod nas se zarana ostvaruju prinosi upravo Željka Mardešića [usp. ovdje, bilj. 4; usp. također: J. JUKIĆ, Sociološki pristup sekularizaciji, Bogoslovska smotra, 45 (1975) 1, 39-48]. Na zastupljenost ove teme u sociologijsko-religiologijskim raspravama ukazuje i slična Mardešićeva konstatacija 1975. (»O sekularizaciji je više napisano posljednjih desetak godina, nego o drugim pojmovima stoljećima "(Jukić, Sociološki pristup sekularizaciji..., 39) i zatim 1997. godine (»Zato je o sekularizaciji više napisano u posljednjih tridesetak godina nego o drugim pojmovima stoljećima « (J. JUKIĆ, Lica i maske svetoga. Ogledi iz društvene religiologije, Zagreb, 1997, 185). 
temeljne problematike, a koju bi najprije sugerirali pojmovi pro-sekularizacija i anti-sekularizacija kao kategorijalno ravnovjesniji. ${ }^{6}$

Unatoč stoljećima prisutnosti jednoga teološki i društveno-religiologijski vidljivoga fenomena u povijesti kršćanstva, ipak se na spomen sekularizacije i $u$ današnje vrijeme mogu očekivati različite asocijacije. Za neke je riječ o odveć poznatoj i već ponešto zamornoj znanstvenoj teoriji, za druge o vjerojatnom, započetom ili i dovršenom društveno-kulturalnome procesu koji je relevantan, ali ne presudan za religiju, a za neke opet tu je možda potrebno vidjeti teorijski izmišljeni problem u odnosu religije i modernoga društva. Teoretičari različitih područja društvenih i humanističkih znanosti različito se odnose prema definiranju same stvarnosti sekularizacije, štoviše, prema tome koliko je i u kojim povijesnim razdobljima potrebno dati na važnosti teoriji sekularizacije modernoga društva, barem u onome osnovnome sociologijsko-religiologijskom određenju u kojemu se ponajviše razvijala tijekom posljednjih sedamdesetak godina. To vrijedi osobito za dva znanstvena područja, za koja se - barem kada je u pitanju kršćanstvo i zapadnjačko kulturalno okruženje - također može reći da su razvoju ove teorije značajno doprinosila, a to su kršćanska teologija i suvremena sociologija religije.

\footnotetext{
${ }^{6}$ Početne i klasične definicije sekularizacije nikada nisu u potpunosti prihvaćene od svih znanstvenika, a niti na oba relevantna znanstvena područja koja ovdje više uzimamo u razmatranje, kao kršćansku i katoličku teologiju i sociologiju religije. Kada bi sekularizacija bila nevaljana znanstvena teorija, o antisekularizacijskome procesu bilo bi zacijelo još teže misliti kao o znanstveno utemeljenoj teoriji. Međutim, sa sekularizacijom je slično kao i s religijom. U sociologiji religije i mutatis mutandis u teološkom diskursu, o sekularizaciji se i raspravlja najviše u izravnoj povezanosti s religijom, odnosno vjerom. Kao kod religije, tako je i kod sekularizacije s većom uvjerljivošću, izgleda, moguće govoriti o uzrocima i posljedicama, o učincima i funkcijama, negoli o tome što je to o čemu se govori. Mardešić na više mjesta ukazuje na taj problem: »Budući da pojam sekularizacije nije moguće nikad dokraja proniknuti (...) mnogi su sociolozi religije počeli svoje zanimanje radije usmjeravati prema uzrocima sekularizacije. Zato sada pitaju: koji su to stvarni uzroci povijesna procesa sekularizacije. Zanima ih, dakle, mehanizam postanka i doseg razvoja sekularizacije u određenu društvu ili čak na svjetskoj razini, a ne njezino sve točnije značenje. To je razlogom da svaka sociologija religije više pretpostavlja smisao pojma sekularizacije nego što ga zaista otkriva. Taj circulum nije moguće posve izbjeći - kao uostalom i u definiranju pojma religije - ali se njegovo djelovanje može oslabiti, što naravno spada u metodička pitanja znanosti o religijama « (Jukić, Lica i maske svetoga..., 198).

${ }^{7}$ Dakako, ovdje ne zapostavljamo važnost filozofijskih pristupa. Njih se ne može previdjeti niti u perspektivi teologijskih niti socio-religiologijskih teoretizacija fenomena sekularizacije. Ipak, problematici sekularizacije ovdje nastojimo približiti se slijedeći s jedne strane relevantnu sociologijsko-religiologijsku misao Željka Mardešića, a s druge strane uvažavajući teološki izravnije ili određenije prinose. O neupitnosti pak socio-religiologijske misli Željka Mardešića, kao one koja se u znanstveno-metodološkome pogledu jasno razlikuje prema filozofiji i teologiji, ne treba dvojiti. Što se prvoga područja znanosti tiče, o tome s kojih znanstvenih pozicija naznačenoj problematici prilazi Mardešić, ilustrira njegova opaska vezana uz sveto, kao ključan pojam u religiologiji: »Suvremena je religiologija jednostavno nefilozofska, okrenuta iskustvu svetoga, povijesti i neposrednosti življenja toga fenomena... « (Jukić, Lica i maske svetoga..., 58). Vezano uz drugo područje znanosti, o Mardešićevu ne samo znanstvenome razgraničenju, nego i afirmativno-kritičkome odnosu prema teologiji uopće, već postoje vrijedna istraživanja [usp. I. ŠARČEVIĆ, Lukavstvo svetog? Mardešićevo razumijevanje političkog katolicizma,
} 


\section{Sekularizacija - od ideologije do društvene ovjere}

Danas malo tko dovodi u pitanje sekularizacijske procese u društvima u kojima je tradicionalna religija kršćanstvo te očitost tih procesa počev najkasnije od novovjekovlja i tijekom moderne povijesti čovječanstva. Pa ipak, može se ponegdje, i od strane samih kršćanskih vjernika, dvojiti o ozbiljnosti ili uvjerljivosti sekularizacijskih procesa, slično, kao što se početkom prošloga stoljeća u Katoličkoj crkvi javljaju nedoumice i iskazuju nespretnosti u sučeljenju s modernizmom i modernitetom. ${ }^{8}$ Te nedoumice i moguće različite percepcije fenomena sekularizacije zacijelo ovise i o različitosti znanstvenih kvalifikacija sekularizacijskih procesa u modernome društvu.

Koliko god se na području znanosti u određenju sekularizacijskih procesa u društvu nalazimo pred lepezom najrazličitijih pristupa i zaključaka, ne preostaje drugo nego prihvatiti kao znanstveno sigurnu i dokazanu teoriju o sekularizaciji modernoga društva zapadnjačkoga civilizacijskoga kruga i sukladno tome, kao općeprihvaćeno ono shvaćanje pojma i stvarnosti sekularizacije koje je omogućio upravo znanstveni napor. Kod toga su, kako se čini, trajno aktualni oni opisi i pokušaji definicija sekularizacije, kakve nalazimo u socio-religiologijskoj literaturi šezdesetih i sedamdesetih godina prošloga stoljeća. Uostalom, oni se i prihvaćaju i koriste $u$ interdisciplinarnome diskursu kao klasični opisi i definicije, što ne mora odmah značiti i nekritičko prihvaćanje pojedinih prognoza o daljnjemu tijeku sekularizacijskih procesa u svijetu, kakve se temelje na dotičnim rezultatima istraživanja sekularizacijskoga fenomena u modernim

Nova prisutnost, 9 (2011) 2, 447-460, 458]. O interdisciplinarnosti i teorijsko-praktičnoj relevantnosti problematike, ocjenjujući vrijednost sekularizacijske teze, Mardešić ukratko primjećuje: »Tu su tvrdnju prvi počeli zastupati filozofi i teolozi, nastavili utvrđivati sociolozi i znanstvenici, a sretno dovršili političari i zakonodavci« [Ž. MARDEŠIĆ, Sekularizacija i odgovori vjernika, Kana, 393 (2006) 11, 14].

${ }^{8}$ Modernizam se ukratko može opisati kao »nastojanje početkom XX. stoljeća da se baština kršćanstva pomiri sa zahtjevima kulture i znanosti toga vremena, što je kulminiralo osudom pape Pija X. u dekretu Lamentabili i enciklici Pascendi (1907.) « [T. JANSEN, Modernizam, u: L. PACOMIO, V. MANCUSO (ur.), Enciklopedijski teološki rječnik (dalje: ETR), Zagreb, 2009, 663-664]. Potreba razlikovanja između onoga što nam sugerira pojam »modernizam «, za razliku od »modernosti« ili »moderniteta «, ujedno daje za pravo mišljenju, da su povijesni procesi nešto što može prethoditi njihovoj teoretizaciji, kako će to Mardešić izreći o sekularizaciji: »Povijesni je tijek sekularizacije prethodio vlastitu teorijsku oblikovanju« (Jukić, Lica i maske svetoga..., 179). Modernizam (i tzv. »antimodernizam «) je u okrilju same Crkve, zapravo njezine teologije, pokušaj teoretizacije stvarnosti koja se tiče odnosa kršćanstva i nove, moderne epohe čovječanstva, odnosa kojemu teorija ne prethodi, nego je njime izazvana. Pojam modernosti sugerira u obliku započete, ili stvarnosti koja već traje, povijesnu periodizaciju koja moderno shvaća kao povijesno razdoblje nečega novoga, a tumačenje modernoga počinje se razumijevati i nazivati svjetonazorom. Mnoga su obilježja i shvaćanja modernosti ili moderniteta, a u pogledu povijesno-periodizacijske sugestije, za našu temu indikativan je sljedeći uvid: »Modernost, dakle, preustrojava ljudsku vremenitost tezom o procesu kao obliku čovjekove povijesne svijesti i tako nadilazi pojam klasične vremenitosti, obilježene osjećajem granice, sekularizirajući kršćansko poimanje vremena « (Dotolo, Modernost, ETR, 665). 
društvima. Dakako, pri tom nije riječ o nekoj jedinstvenoj i sveobuhvatnoj definiciji sekularizacije, koliko više o pokušaju tumačenja uzroka i učinaka sekularizacijskih procesa, a to je upravo ono što kao općenito, u smislu temeljne percepcije, danas i shvaćamo pod pojmom sekularizacije. ${ }^{9}$

Priznati autoriteti na području sociologije religije, koji istražuju sekularizacijske procese od početka prošloga stoljeća do danas, poput P. Bergera i B. Wilsona, razlikuju u pogledu uzroka i učinaka sekularizacije subjektivni i objektivni vid, odnosno unutarnje i vanjske razloge pojave sekularizacije. Pojednostavljeno, prema njihovim interpretacijama, već se na razini religijskih institucija, kao što su kršćanske Crkve, događa slabljenje same institucije kao takve, pojava religioznoga izbora i redukcija učinkovitosti Crkve kao autoritativne religijske ustanove, što su ipak za sam fenomen sekularizacije manje relevantni njezini unutarnji razlozi, ${ }^{10}$ ali se onima vanjskima, poput laicizacije života, autonomnosti politike i morala, pojave potrošačkoga mentaliteta i sl. trebaju pripisati izravni učinci potiskivanja religije na rub društvenoga života očiti u sve većoj svjetovnosti moralnoga života. ${ }^{11}$

Prema Bergeru, sekularizaciju potiču zbivanja u okrilju samoga kršćanstva, kao i moderni racionalizam koji podjednako pospješuju desakralizaciju društva, a najveći naglasak u smislu posljedica razvoja sekularizacijskih procesa ovaj će sociolog religije staviti na neupitnost pojave tzv. »religijskoga tržišta«, koje je obilježeno slobodom religijskoga i religioznoga pristanka, pojavom pluralizma i slabljenjem crkvenih ustanova. ${ }^{12}$ Ovim - po sebi dakako puno složenijim i obuhvatnijim rezultatima istraživanja - svojevrsnu nadopunu u smislu klasičnoga sociologijsko-religijskoga određenja pruža djelo Karela Dobbelaerea, ${ }^{13}$ koji se odvažio na »najopširniju definiciju fenomena sekularizacije, uzimajući u obzir sve dosadašnje znanstvene prinose sociologijske discipline u pogledu razjašnjenja toga fenomena $\ll^{14}$ Dobbelaere razlikuje bitne dimenzije sekularizacije, od kojih je prva laicizacija, druga promjena religijsko-religiozne situacije u društvu, treća se tiče samih religijskih promjena. Slijedom i takvih distinkcija, konačno se kao ključni obrat ističe preobrazba na razini etike i morala. ${ }^{15}$

\footnotetext{
${ }^{9}$ Iako u suvremenosti postoje relevantni pokušaji definiranja sekularizacije - počev od sredine prošloga stoljeća, kada se u tom pogledu obično ističu američki sociolozi religije Harold W. Pfautz i Milton J. Yinger - o takvome općenitijemu stanju pobližega određenja pojma i stvarnosti sekularizacije, Mardešić primjećuje: »Možda zvuči paradoksalno, ali danas u sociologiji religije više znamo koliko je društvo sekularizirano nego što to znači da je sekularizirano. Vjerojatno je to posljedica činjenice da je istraživanje o svjetovnosti svijeta počelo mnogo ranije nego samo njegovo određenje (Jukić, Lica i maske svetoga..., 191).

${ }^{10}$ Usp. Wylson, Religion in Secular Society..., 36.

${ }^{11}$ Usp. isti, Religion in Sociological Perspective, Oxford, 1982, 159 slj.

${ }^{12}$ Usp. Berger, The Sacred Conopy..., 127-153.

${ }^{13}$ K. DOBBELAERE, Secularization: A Multidimensional Concept, London, 1981.

${ }^{14}$ Jukić, Lica i maske svetoga..., 189; usp. S. TADIĆ, Sekularizacija, antisekularizacija..., 26-28.

${ }^{15}$ Usp. D. MARTIN, A General Theory of Secularisation, Oxford, 1978, 83 slj.
} 
Kod većine teoretičara sekularizacije upravo će se o tome obratu možda zatim i najviše promišljati, ovisno o složenosti suodnosa religije i sekularizacije na području društvene zbilje, to jest o poteškoći koja proizlazi iz nesuglasja oko shvaćanja i opisivanja obiju stvarnosti, od kojih se religija u nekome pokušaju pobližega određenja čini još i teže razumljivom stvarnošću, ${ }^{16}$ što ne mora biti slučaj s pokušajem prepoznavanja i društvenoga vrednovanja njezinih moralno-etičkih postavki. Slično je to bilo već i na samim počecima naznaka o kasnijemu razvoju teorije o sekularizaciji, ${ }^{17}$ koji mnogi još uvijek povezuju $\mathrm{s}$ Weberovim pojmom »raščaravanja svijeta« (Entzauberung) ${ }^{18} \mathrm{u}$ čijim se sociologijskim raspravama pojam sekularizacije inače tek usputno pojavljuje. ${ }^{19}$ Weberovsko »raščaravanje« ipak se najviše odnosi na racionalizaciju kršćanske etike u građanskome društvu.

Dakako da se tu odmah postavlja pitanje dinamike odnosa religija-etikasekularizacija, dotle da je moguće o sekularizaciji misliti izravnije u odnosu prema etici negoli religiji, odnosno moralu i etici bez obzira na religiju, što je ipak teško prihvatljivo polazeći od svih sociologijsko-religiologijskih određenja značenja sekularizacijskih procesa, makar i više kroz smisao nego značenje, kroz uzroke i učinke nego pretpostavljeni ili stvarni sadržaj. Kada se stoga na počecima razvoja teorije o sekularizaciji - makar i samo u razvojnoj klici, kako to proizlazi iz shvaćanja Weberova pojma »raščaranosti« kao izvjesne paradigme za proces »racionalizacije kršćanske etike u građanskome društvu $\aleph^{20}$ koje se sve više osamostaljuje - još nedostatno razlikuje sveto i religija, religija i moral, etičke i društvene vrijednosti, odnosno norme ponašanja, a nalazimo se u kontekstu prosvjetiteljske kritike religije, ne treba čuditi da je i govor o raščaranosti i sekularizacija kao društvena pojava, sada neovisni o Crkvi ili kršćanstvu, nešto što se ne sasvim bezrazložno percipira svojevrsnom ideologijom novoga - a mnogi bi ga vjerojatno tako i danas nazvali - »bezbožnoga« društva i »bezbožnoga« svijeta.

\footnotetext{
${ }^{16}$ Mardešić piše o neuspjehu u određivanju religije, jer su poteškoće s tim povezane jednako na strani objekta, subjekta i metode, tako da je i njegovo opredjeljenje u kontekstu ove problematike više na strani fenomenologijskoga pokušaja određenja svetoga kao krajnje i zajedničke svedivosti fenomena religioznosti (usp. Jukić, Lica $i$ maske svetoga..., 21-65). O najnovijim proukama s tim u vezi v.: G. ČRPIĆ, J. ĆURKOVIĆ NIMAC, Ž. TANJIĆ, Vjersko uvjerenje $i$ moralno ponašanje. Teorijska rasprava $i$ empirijska analiza o utjecaju religije na moral u hrvatskom kontekstu (Religija), Zagreb, 2016, 94-109; usp. također: S. KUŠAR, Djelomično prihvaćanje vjere - kršćanstvo po izboru, Bogoslovska smotra, 66 (1996) 2-3, 319345.

${ }^{17}$ Iako se i Weberov pojam »raščaranosti svijeta« odnosi na istu stvarnost, na području sociologije religije znanstveno-terminološki status pojma »sekularizacije« jasnije se uočava kod Troeltscha (usp. E. TROELTSCH, Die Bedeutung des Protestantismus für die Entstehung der modernen Welt, München, 1928, 48).

${ }^{18}$ Pojam se najprije javlja u njegovu glasovitome djelu »Wissenschaft als Beruf« iz 1919. godine.

${ }^{19}$ Usp. M. WEBER, Wirthschaft und Gesellschaft. Grundriss der verstehenden Soziologie, Tübingen, 1964, 892.

${ }^{20}$ Usp. E. ROGGERO, La secolarizzazione controversa, Milano, 1979, 65.
} 
Je li i danas dokraja očito da je teorija o sekularizaciji, čak i onda, kada je riječ o empirijski izvedivim sociologijskim istraživanjima, neutralna znanstvena teorija koja nije smišljena kao neka »teorija zavjere« kojom se želi nauditi Crkvama i kršćanstvu Zapada? Nekoliko povijesno-razvojnih naznaka dostajat će za razumijevanje, zbog čega je i danas na upravo postavljeno pitanje neizvjesno očekivati u potpunosti pozitivan odgovor, barem što se njegove podudarnosti s adekvatnim uvjerenjima pojedinih kršćanskih vjernika današnjice zacijelo tiče.

Čini se da na području kršćanske misli pretkoncilskoga razdoblja sekularizacija i nije toliko uvažavana kao ozbiljna znanstvena teorija - što ona naglašeno i postaje najvećma na području sociologije religije tek od sredine prošloga stoljeća - u percepciji teoretske razgradnje kršćanstva kao društveno relevantne stvarnosti. O onome što se doskora shvaća kao sekularizacijski proces $u$ društvu, u izravnoj ili neizravnoj kritici kršćanstva kao tradicionalne religije nekog kulturalnoga podneblja, ${ }^{21}$ ipak se $u$ toj istoj kršćanskoj misli već zarana vodi računa, sve ako se sekularizacija smješta pod opću stvarnost moderniteta, percipiranoga kao liberalno-građansko i prosvjetiteljski određeno areligiozno pa i antireligiozno, ideologizirano (pseudo)znanstveno nastojanje oko određenja i funkcionalnosti modernoga svijeta. Primjera je mnogo, poput sljedećega pitanja, koje dvadesetih godina prošloga stoljeća postavlja istaknutiji hrvatski teolog i publicist:

»Nije li sav naš život i politički i gospodarski i prosvjetni posvema dekristijaniziran? Gdje se danas osjeća da je ova Hrvatska katolička zemlja?!«22

Možemo u tome osjetiti nostalgiju za prošlim vremenima snažnijega utjecaja Katoličke crkve i kršćanstva na svijet i društvo, ali ne možemo previdjeti približnu točnost procjene stanja i uvažavanje onoga što će drugi u isto vrijeme započeti opisivati kao sekularizacijske procese, sve ako se kršćanima tada još moglo činiti da je riječ o čistoj ideologizaciji i konstruiranju stvarnosti, čemu se onda trebaju suprotstaviti u obrani svojih vjerskih načela i zaradi svoje odgovornosti prema Bogu, čovjeku i društvu. Postoje, međutim, i drukčija gledišta, čak i desetljeća kasnije, poput svojevrsnoga ignoriranja stvarnosti. Tako upravo Mardešić kritički ukazuje na sociologijska promišljanja katoličkoga teologa fra Bonifacija Perovića:

»Znakovito je još da fra Bonifacije Perović gotovo nigdje u svojim knjigama ne spominje proširenost sekularizacije u modernome društvu, jer bi onda morao

\footnotetext{
${ }^{21}$ Filozofijska i njome nadahnuta moderna kritika religije u svojim počecima, u prosvjetiteljstvu, možda je izravnije vezana uz kritiku kršćanstva kao dominantne religije u kulturalnome podneblju u kojemu se takva kritika i pojavljuje, ali pri tom bi možda bilo ispravnije tu najraniju fazu kritike religije shvaćati kao antiklerikalnu i antikatoličku, a ne općenito antireligioznu, što će više postati slučaj tijekom vremena, pa i u onome povijesnome odsjeku, koji ovdje imamo u vidu.

${ }^{22}$ S. BAKŠIĆ, U znaku dvaju jubileja, Katolički list, 76 (1925) 1, 8.
} 
priznati da bi bez pomoći mikrosociologije ta pojava ostala dugo prešućena i možda sustavno potisnuta. $\ll^{23}$

Oštrijom se čini njegova kritika općenite situacije na području domaće katoličke teologije, dok se još uvijek u nekoj oprjeci prema zasebnoj znanstvenoj grani sociologije religije smatralo poželjnim i mogućim uspostaviti svojevrsnu »kršćansku« sociologiju, kao nemoguću sastavljenost socijalnoga nauka Crkve i argumentativno instrumentaliziranih podataka društvenih znanosti:

»To je uostalom u onodobnoj katoličkoj teologiji bilo gotovo uobičajeno, pa je recimo J. Kuničić mogao svoju knjigu o društvenom nauku Crkve iz 1971. godine nazvati katoličkom sociologijom, premda sociologija može biti katoličkom upravo onoliko koliko biologija, fizika, matematika, astronomija ili gospodarstvo, što znači nikako i nikada. Danas su te metodičke razlike posve jasne i nikome ne pada na pamet da bi pomiješao teologiju s društvenom znanošću ili nekim drugim znanostima uopće. « ${ }^{24}$

Ovim se Mardešićevim objekcijama, dakako, nema što prigovoriti. ${ }^{25} \mathrm{~S}$ druge strane, situaciju koju nam dočaravaju izneseni primjeri itekako možemo razumjeti i za takvo razumijevanje također pronaći dostatne razloge u samim Mardešićevim promišljanjima.

Sredinom prošloga stoljeća, unatoč sve boljemu poznavanju sekularizacijskih procesa u svijetu, usporedno s osnovnim proukama religiologijski relevantnih društvenih promjena, postavljaju se i različite znanstvene teorije. Među njima je i ona o modernizaciji društva čija je nužna posljedica njegova sekularizacija. Svi koji su se osjetili zabrinuti za budućnost religije u tako postavljenoj prognozi mogli su prepoznati obnovljene prosvjetiteljske ideje uključene u tezi »da sigurnost koju čovjek dobiva napretkom društva smanjuje njegovu potrebu za traženjem eshatološkoga spasenja«. ${ }^{26}$

Ono što se u kršćanskoj tradiciji poima kao eshatološko spasenje, još se u weberovskom pojmu »raščaranosti« dotiče uvjeta i mogućnosti društvene preobrazbe religioznih i teoloških sadržaja, makar u izravnijemu pokušaju racionalizacije, zapravo dekristijanizacije i desakralizacije građanske etike, sve ako se ta etika neće u potpunosti udaljiti od sadržajnih i funkcionalnih predodžbi zamišljene kršćanske etike, ${ }^{27}$ ali će u suprotstavljenosti prema njoj

${ }^{23}$ J. JUKIĆ, Od radničkog pitanja do vizije hrvatskoga društva, Bogoslovska smotra, 69 (1997) 4, 498.

${ }^{24}$ Isto, 497.

${ }^{25} \mathrm{Ne}$ kao prigovor, nego pojašnjenje, možemo samo podsjetiti da je u starijoj teološkoj literaturi čest slučaj terminološkoga određenja socijalnoga nauka Crkve uporabom pojma »sociologija ", čime se ne misli odmah na zasebno znanstveno područje sociologije, nego na analizu društva smještenu u okvire razvoja novih, suvremenih teoloških znanstvenih disciplina, čije nazivlje je danas, dakako, primjerenije.

${ }^{26}$ N. MALOVIĆ, Laičnost - prilike i zablude, Crkva u svijetu, 50 (2015) 3, 427.

${ }^{27}$ Pitanje »kršćanske etike « u povijesti filozofije, ali i teologije, prilično je diskutabilno [više o tome: Črpić, Ćurković Nimac, Tanjić, Vjersko uvjerenje i moralno ponašanje, (Religija i moral)..., 121-161]. Nama se u tom pogledu čini posve uvjerljivim Mardešićevo isticanje specifičnih 
prijašnje eshatološko spasenje radije poimati kao društveni napredak u obliku ekonomskoga i znanstveno-tehničkoga razvoja, što je onda zapravo jedan od kršćanskih »sekularizata «. ${ }^{28}$ Nije odveć teško razumjeti otpore tako postavljenim tvrdnjama afirmativnim za teoriju sekularizacije, u kojima se jednako osjeća kritika religije (zapravo kršćanstva) i desakralizacija, sekularizacija ne samo onoga što se povijesno može utvrditi i kao proces unutar samoga kršćanstva, nego i onoga što ipak spada na osnove kršćanske objave i njezine vjere, a dolazi na način kršćanstvu izvanjske kritike.

Teologija kao znanost, osobito katoličke provenijencije, znala je na slične pojave odgovoriti možda i odveć kritički nemilosrdno, što je danas, nakon što su ove početne nejasnoće oko nastanka teorije sekularizacije manje važne $u$ suvremenome interdisciplinarnome znanstvenom diskursu, teško uočiti bilo gdje i od bilo koga. ${ }^{29}$ Sljedeće razmišljanje čini se vrlo ilustrativnim za takav odgovor, sve ako se ni ne odnosi izravno na problematiku sekularizacije kao sociologijske teorije:

»Ne zaboravimo da je taj čovjek koji zna i koji misli umjesto nas u biti sociolog, onaj koji razmišlja o društvenoj rekonstrukciji. Filozofski pozitivizam obilježen je nastupom sociologije: religiozni će dakle pozitivizam poprimiti oblik 'sociolatrije' i 'sociokracije'. Ondje će se 'društvena fizika' okruniti društvenom mistikom, a religija Čovječanstva, da ne bi ostala apstraktna i sasvim unutarnja, utjelovit će se u vladavini Društva. Sve je kršćanstvo, u konačnici, iščekivanje kraljevstva nebeskoga, sav je pozitivizam, u konačnici, iščekivanje kraljevstva zemaljskoga. Bilo bi dakle ondje uzaludno razlikovati religiozni dio od političkog dijela: politika je, u širem značenju te riječi, ukupan sadržaj te religije, ona uspostavlja 'konačnu svrhu dogme i kulta, koji se na taj način čuvaju od svake asketske i kvijetističke devijacije, slijedeći poriv istinske ljubavi'. Ako je nastup sociologije uzdignuće politike na rang promatračkih znanosti' (Comte), nastup sociokracije bit će religiozna posveta te politike. « ${ }^{30}$

Naravno da ovakvo kritičko preispitivanje za Mardešića nije ni neočekivano ni nepoznato. Štoviše, on sam često opisuje razloge nekih nesporazuma tijekom povijesti:

»U svakom slučaju, za katoličku je misao bila izrazito nesretna okolnost što se sociologija povijesno oblikovala pod znakom filozofijskog pozitivizma, koji

»odrednica religije« koje su u kršćanstvu raspoznatljive kao »visoko etične« (usp. Jukić, Lica $i$ maske svetoga..., 22).

${ }^{28} \mathrm{O}$ tvorbi i uporabi neologizma sekularizat v.: Kušar, Djelomično prihvaćanje vjere..., 341.

${ }^{29}$ Umjerenije prosudbe s tim u vezi iznosi sociolog Hans Joas, koji zaključuje da nastanak teorije sekularizacije u obliku prethodno opisane teze nije dokraja ni istražen, a prognoza o nestanku kršćanstva s lica zemlje svejedno se može pratiti počev od 18. st. (usp. H. JOAS, Glaube als Option. Zukunftsmöglichkeiten des Christentums, Freiburg im Breisgau, 2013, 23 slj.). Kao neko opravdanje takvih prognoza, Joas ističe tri tipa religije ili tumačenja religijske vjere, koja se javljaju u teoretizaciji odnosa sekularizacije i kršćanstva, a jer su sve pogrešne, netočne su i prognoze o nestanku kršćanstva uslijed sekularizacijskih procesa (usp. isto, 29 slj.).

${ }^{30}$ H. de LUBAC, Drama ateističkog humanizma, Rijeka, 2008, 236. 
se bez sustezanja otkrivao kao ateistična i protucrkvena ideologija masovnih razmjera. To je razlogom da se uz shvaćanje sociologije kao strogo pozitivne i empiričke znanosti, također proširilo i shvaćanje sociologije kao filozofije i ateističke ideologije, posebice u katolika, koji su je tako i doživljavali. Ne treba se onda čuditi što su službeni predstavnici Crkve i teolozi s razumljivim nepovjerenjem gledali na sociologijsku znanost, jer je ona u krajnjoj crti ozbiljno potkopavala temelje institucionalnog kršćanstva. $S$ vremenom su se ipak stvari počele mijenjati. « ${ }^{31}$

Ako je tako sa shvaćanjem sociologije u prošlosti, još je razumljivija odbojnost katoličkih intelektualaca prema teoriji o sekularizaciji, ponovno, i na svu sreću, izrazitije u prošlosti. Tu, međutim, neko opravdanje takvih otpora nalazimo i u samome kontekstu povijesno-sociologijskih istraživanja i prevrednovanja razvojnih etapa socio-religiologijske znanosti, o čemu nam ponovno iscrpne analize i argumentirane zaključke pružaju Mardešićeva promišljanja. Ponajprije, važna je njegova konstatacija da u novije vrijeme i »sve veći broj sociologa zastupa mišljenje da je sekularizacija daleko više ideologijska tvorba negoli je društvena teorija«, ${ }^{32}$ pri čemu osobito ističe Glasnerovo ${ }^{33}$ stajalište. Još rezolutnijim ocjenjuje mišljenje Davida Martina, ${ }^{34}$ prema kojemu bi suviše različite uporabe pa i zloporabe pojma sekularizacije bili ne samo zapreka sociologiji religije kao znanosti, nego bi sekularizacija bila »više sredstvo antireligiozne promidžbe nego strogo znanstveni pojam«.35

Kritička preispitivanja na području sociologije religije, u potrazi za obuhvatnijom znanstvenom paradigmom religiologijski relevantnih društvenih procesa koji se nastoje obuhvatiti pojmom sekularizacije, potaknula su doduše i takve teorijsko-praktične razvoje koji su čak iznjedrili pretpostavke za preobrazbu sociologije u neki od oblika svjetovne religije, ${ }^{36}$ što je, dakako, također uključivo u vidokrug spomenute de Lubacove kritike. Željko Mardešić, unatoč tome što je svjestan i ideologijski obilježenih početaka sociologijskih promišljanja, jednako je uporan $\mathrm{u}$ isticanju prevladanosti takvih razdoblja u povijesnome razvoju sociologije kao pozitivne znanstvene grane. ${ }^{37}$ Slično je i s njegovim shvaćanjem teorije o sekularizaciji, odnosno, sekularizacije kao povijesno-procesne stvarnosti, bez obzira je li odmah riječ o sustavnoj i dokazanoj znanstvenoj teoriji ili zaključivanju na temelju analize religiozne i društvene stvarnosti. Tako će u

\footnotetext{
${ }^{31}$ Jukić, Od radničkog pitanja do vizije kršćanskoga društva..., 483.

${ }^{32}$ Usp. Jukić, Lica i maske svetoga..., 209.

${ }^{33}$ Usp. P. E. GLASNER, The Sociology of Secularization. A Critique of a Concept, London, 1977.

${ }^{34}$ Usp. D. MARTIN, The Religious and the Secular, Essays in Secularisation, London, 1969, 9.

${ }^{35}$ Usp. Jukić, Lica i maske svetoga..., 210. Slično će o stajalištima ovoga sociologa desetak godina kasnije pisati i Tadić, apostrofirajući Martinovo zalaganje »da se termin sekularizacija, zbog niza značenja, heterogenosti i neodredljivosti izbaci iz sociološkoga rječnika« (usp. Tadić, Sekularizacija, antisekularizacija..., 31).

${ }^{36}$ Usp. F. FERRAROTTI, Una teologia per atei. La religione perenne, Rim, 1983, 196.

${ }^{37}$ Usp. Jukić, Lica i maske svetoga..., 57.
} 
svojim prvim znanstvenim obradama fenomena sekularizacije oprezno i nepristrano započeti konstatacijom:

"Živimo u vrijeme eskalacije šokantnih pojmova. Ideologije lansiraju na tržište ideja golemi broj krilatica i fraza, puštajući ih da kratko žive, a kada iščeznu, onda ponovno izmišljaju nove. (...) Jedna od tih krilatica jest: sekularizacija. Izbačena iz ideološkoga pentagona, ona danas osvaja svijet.«" ${ }^{38}$

Međutim, postoji i daljnje, socio-religiologijsko istraživanje i zatim poimanje ovoga fenomena, o čemu također započinje - mogli bismo tako reći - i svojevrsna Mardešićeva potraga za obuhvatnijom paradigmatskom odredbom sekularizacije, ali u strogoj navezanosti na sociologijska istraživanja kod kojih se uvažavaju dotični rezultati koji su motivirani neprevidivim pastoralnim razlozima, a i koji se mogu znanstveno sociologijski ispitivati ne bez obzira, ali ne ni u ovisnosti o ateističkoj ideologizaciji u socijalističkim društvima. Također ne ni strogo u ovisnosti o istraživanjima i interpretacijama sekularizacije u građanskim društvima Zapada, u kojima se možda premalo uvažava konkretna pojavnost religije, tj. kršćanstvo. Mardešićevo istraživanje sekularizacije fenomenologijskim pristupom potvrđuje učinke sekularizacije kao »unutrašnje slabljenje, hlađenje, udaljavanje, odumiranje i splasnuće zanosa vjerovanja «, ${ }^{39}$ kako to prvenstveno opaža primijenjeno na kršćanstvo.

Mardešićevi nalazi znanstvenih istraživanja fenomena sekularizacije, slijedom rečenoga, mogu se ipsissima verba odrediti kao »društvena ovjera sekularizacije «. ${ }^{40}$ Ta se ovjera sastoji u prepoznavanju i analizi jasnih pokazatelja sekularizacijskih procesa upravo na onim područjima društvene prisutnosti kršćanstva kao tradicionalne religije, na kojima je svjetovni duh najizrazitiji, a to su moderni gradovi i industrijski razvijenija područja. Mardešić nabraja osam pokazatelja uznapredovale sekularizacije, uvažavajući rečeni društvenoživotni kontekst: opadanje vjerske prakse; nepostojanje utjecaja religioznosti na svakidašnji vjernički život; disolucija dogmatskoga vjerovanja; generacijska redukcija sudionika u vjerskim obredima i obavljanju vjerničkih dužnosti; kriza obitelji; udaljavanje društvenih slojeva, poput radništva, od Crkve; manjak svećeničkih zvanja i porast starosne dobi. ${ }^{41}$ Ovo će, u daljnjoj razradi uz pojedine dopune, Stipe Tadić nazvati tzv. »kompleksnim pristupom Jakova Jukića « ${ }^{42}$ problematici sekularizacije.

Novija empirijski temeljena istraživanja u zajedničkome naporu domaće i međunarodne znanstvene zajednice ovoj će društvenoj ovjeri dati svojevrsnu potvrdu, iako će ujedno i egzaktnije utvrditi stvarno stanje stvari, poglavito $\mathrm{s}$ obzirom na hrvatske prilike i njihovu komparativnu zahvaćenost sekularizacij-

\footnotetext{
${ }^{38}$ Jukić, Sociološki pristup sekularizaciji..., 39.

${ }^{39}$ Usp. Jukić, Lica i maske svetoga..., 192.

${ }^{40}$ Usp. isto, 191-198.

${ }^{41}$ Usp. isto, 196-198.

${ }^{42}$ Usp. Tadić, Sekularizacija, antisekularzacija..., 28-30.
} 
skim procesima u kontekstu europskih društava. ${ }^{43} \mathrm{U}$ pogledu aktualnosti Mardešićevih analiza i prognoza stanja, čini se da u našemu tranzicijskome društvu još uvijek nismo do kraja svjesni dinamike sekularizacijskih procesa, barem što se tiče njihove neupitnosti u tradicionalno kršćanskim europskim društvima, poput našega ${ }^{44}$ Zbog toga je njegova fenomenologijska analiza tih društava i napor u utvrđivanju i interpretaciji pokazatelja društvene ovjere sekularizacije sve aktualniji izazov svima onima kojima je stalo do razumijevanja religiologijski relevantnih preobrazbi društva i kulture u kojima žive. Kako, međutim, stvari stoje s eventualnom teološkom i slijedom toga crkvenom ovjerom sekularizacije, nastojat ćemo istražiti u sljedećemu odsjeku.

\section{Sekularizacija - od teološke do crkvene ovjere}

Iako bi ovakav naslov poglavlja, nakon što je sekularizacija dugo bila gotovo izrazita tema kršćanske teologije - najprije protestantske, a zatim i katoličke, i to upravo kao teološka tema, kao teološki problem i kao naglašena teološka perspektiva zauzetoga promišljanja o odnosu kršćanstva i suvremenoga svijeta - sada već mogao sugerirati neko prevladano razdoblje u povijesti kršćanstva novijega vremena, čini nam se poticajnim za našu temu iz dvaju poglavitih razloga. Prvo, u promišljanjima Željka Mardešića često se može opaziti svojevrsno - ako se tako smije reći za jednoga znanstvenika koji stvari najradije promatra na razini fenomena - »nezadovoljstvo « činjenicom da se kod nas teološki o sekularizaciji nedovoljno raspravlja, piše, istražuje. ${ }^{45}$ Dobri fenomenolozi, poput Mardešića, o stvarima koje istražuju razmišljaju bez predrasuda, s nakanom da se ustanovi što više činjenica, jer nepoznavanje činjenica znači svojevrsno projiciranje stvarnosti:

»Tko se ljuti na činjenice, taj se nalazi uvijek vremenski prije samih činjenica. (...) Znati unaprijed sve o stvarima, znači zapravo o njima još ništa ne znati.« ${ }^{46}$

\footnotetext{
${ }^{43}$ Usp. J. BALOBAN, K. NIKODEM, S. ZRINŠČAK, Vrednote u Hrvatskoj i Europi. Komparativna analiza, Zagreb, 2014; G. ČRPIĆ, S. ZRINŠČAK, Dinamičnost u stabilnosti. Religioznost u Hrvatskoj 1999. i 2008. godine, Društvena istraživanja, 19 (2010) 1-2, 3-27; S. ZRINŠČAK, S. KUŠAR, G. ČRPIĆ, Vjerovanje i religioznost, Bogoslovska smotra, 70 (2000) 2, 233-255.

${ }^{44} \mathrm{Na}$ više mjesta u svojim radovima - od prvih do posljednjih - Mardešić o tome zaključuje na sljedeći način: »Za svaku društvenu znanost koja kani ozbiljno i odgovorno raspravljati o svetome, sekularizacija je danas postala njezin nepreskočiv okvir. Jer, koliko da se upiremo, iz toga okvira nećemo nikako uspjeti izaći. Sve su naime razvijene zemlje u naše doba već posve sekularizirane, a one Trećega svijeta i poskomunističkog poretka velikom brzinom ulaze jednako u taj obzor svjetovnosti« (Jukić, Lica i maske svetoga..., 179).

${ }_{45} \gg \mathrm{U}$ hrvatskom društvu sekularizacija se još nije razmahala, a vrijeme za njezinu teologijsku obradu zacijelo odmaklo, pa je vjerojatno neće ni biti. (...) No sekularizacije ima i bit će je sve više...« [Ž. MARDEŠIĆ, Sekularizacija i teologija, Kana, 377 (2004) 5, 15].

${ }^{46}$ Mardešić, Rascjep u svetome..., 488.
} 
Ako se Mardešić ne zadovoljava znanstvenom pažnjom koja se na području naše domaće teologije tijekom novijega vremena posvećivala problematici sekularizacije, to onda treba najprije shvatiti, u polazištu, kao očitovanje u skladu s njegovim općenito konstruktivnim zalaganjem za svaki oblik dijaloga, pa i onaj znanstveni, ${ }^{47}$ a s druge strane, i kao primjedbu koja se ne odnosi na zastupljenost sekularizacijske problematike općenito u povijesti teoloških istraživanja, nego kao iznošenje uvjerenja da je upravo ta problematika relevantna i za današnju, suvremenu teologiju kao teologiju. Zbog toga nam se čini, kao drugo, tragom ranijega uvažavanja Mardešićeva govora o društvenoj ovjeri sekularizacije, u okviru ovoga poglavlja istaknuti onaj put koji je recepcija i percepcija sekularizacije prošla na razini institucionalnih struktura kršćanstva od ignoriranja, preko neprihvaćanja do ozbiljnoga uvažavanja - dakako, ne niti u svim segmentima totaliteta ovoga fenomena niti jednoznačno - što onda nije iznimka niti na našemu, hrvatskome prostoru, samo se možda odražava na način, kao i većina općih i kulturalno divergentnijih kršćansko-teologijskih problematika na svjetskoj crkvenoj razini, to jest u obziru prema specifičnostima našega kulturalnoga podneblja, ali i prema konkretnostima uvjeta i mogućnosti aktualnoga razvoja domaće znanstveno-teološke misli.

Kao svojevrsni uvod u skiciranje rečenoga puta, zanimljivim se čini Mardešićevo shvaćanje odnosa Crkve i teologije prema općenitim izazovima suvremenih pojava u društvu i kulturi: »Ako je već Crkva nepovratno zakasnila predvesti velike povijesne pokrete slobode i oslobođenja - seljaka, radnika, mladih, obojenih, rubnih, starih i nemoćnih - pokušala je to barem nadoknaditi njezina neposlušna teologija. ${ }^{48}$ Pri tom konkretno misli na drugi od dva teologijska razvojna pravca, koji se izvorno na europskome tlu, a zatim i na svjetskoj znanstvenoj razini u različitim transformacijama napose bave problematikom moderniteta, sekularizacije i društvene emancipacije sredinom prošloga stoljeća i kasnije, a koje, kao i općenito prihvaćeno, prema Duquocu ${ }^{49}$ naziva $\left(\right.$ (svjetovnom) teologijom svijeta $« \mathrm{i} »$ teologijom (kritične) slobode $\ll{ }^{50}$ Imamo li u vidu i Mardešićeve znanstvene analize tzv. »teologijske kritike religije,$^{51} \mathrm{u}$ kojima su uključeni svi važniji predstavnici suvremenih teologijskih razrada se-

\footnotetext{
${ }^{47}$ Ta prosudba daje se naslutiti u sljedećemu, općenitijemu opisu karakteristika Mardešićevih razmišljanja i pisanja: »Što zbog svoga nekonfliktnoga, ali time nipošto kompromiserskog već istinoljubivo-pitalačkog karaktera, što zbog stalne pozornosti da ne bi koga nepravedno povrijedio i izrekao krivi sud, što zbog skromnosti i nepretencioznosti - jer nije imao formalno obrazovanje iz sociologije religije, Mardešić budno pazi na svaku riječ: koliki im je opseg, kako se razlikuju međusobno i koje im je najprikladnije mjesto u rečenici« (I. ŠARČEVIĆ, Lukavstvo svetog? Mardešićevo razumijevanje političkog katolicizma, 447).

${ }^{48}$ Ž. MARDEŠIĆ, Crkva i suvremeni svijet. Današnje perspektive, Bogoslovska smotra, 75 (2005) 3, 918.

${ }^{49}$ Usp. Ch. DUQOUC, La théologie en exil. Le défi de sa survie dans la culture contemporaine, Pariz, 2002, 44-47.

${ }^{50}$ Usp. Mardešić, Crkva i suvremeni svijet..., 915-917.

${ }^{51}$ Usp. Jukić, Lica i maske svetoga..., 26-30.
} 
kularizacijske problematike kao teološke teme, njegovim sustavnim prikazima i procjenama, s kojima se ponajviše može usuglasiti i povijesno-teološka kritika dotičnih pristupa, najavljeni put od teološke do crkvene ovjere u nastavku se može djelomično skicirati također povremenim slijedom njegovih uvida i socio-religiologijskih prosudbi, koje redovito očituju impresivnu teološku kompetenciju.

U teološkim promišljanjima sekularizacija postaje kao složeni locus theologicus, što je razlogom različitoga i ponekad suprotstavljenoga shvaćanja fenomena, ništa manje nego u filozofiji ili sociologiji, štoviše, možda i s većim međusobnim odstupanjima, ovisno o temeljnim problemskim pristupima pojedinih teologa. Zato je i sekularizaciju kao pojam strogo teološki jednako teško precizno odrediti, kao što je to slučaj i u sociologiji religije, dakako, ako se želi odgovoriti na pitanje što je točno taj fenomen, a ne prvenstveno koji su mu uzroci i vidljivi istraživi učinci u pojedinim segmentima javnoga i privatnoga života.

U znanstvenoj obradi sekularizacijske problematike zanimljiva je podudarnost među znanstvenicima različitih područja, od filozofa i teologa, preko sociologa, religiologa i psihologa religije, do politologa i pravnika o prihvaćanju dvostrukoga značenja sekularizacijskih procesa u modernome društvu. $S$ jedne strane sekularizacija se povijesno shvaća u onome terminološkome značenju kojim se misli na unutarcrkveno pitanje svođenja klerika ili redovnika na laički stalež. Oduzimanje crkvene imovine od strane svjetovne vlasti - nakon okončanja vjerskih ratova u 17. stoljeću, tijekom Francuske revolucije i u napoleonsko doba u 18. i 19. stoljeću, a zacijelo i u sličnim postupcima za vrijeme apsolutizama i diktatura u 20. stoljeću - također se, zajedno s prvim oblikom, terminološki i pojmovno može odrediti kao sekularizacija u njezinu prvotnome, pravnome značenju.

Na prijelazu iz 19. u 20. stoljeće značenje pojma se proširuje i u svojoj kulturološkoj primjeni koristi za označavanje onih promjena u društvu, jednako na razini institucija i društvenih staleža ili skupina, u kojim se očituje sve veća emancipacija cjelokupnoga znanstvenoga, kulturalnoga i društvenoga života od crkvenoga utjecaja, bilo da je pri tom riječ o legislativnim promjenama, bilo o samim pojavnim stvarnostima na razini društvenoga života. Ta dva osnovna značenja sekularizacije, koja se javljaju od najranijih početaka prepoznavanja sekularizacijskih događanja na crkvenome i društveno-kulturalnome području, brzo se znanstvenim teoretizacijama proširuju u smislu i shvaćanju. ${ }^{52} \mathrm{Sa}$

\footnotetext{
${ }^{52}$ Filozofija će u sekularizaciji vidjeti izrazitu hermeneutičku kategoriju modernoga doba, koja u pojedinim filozofijama povijesti omogućuje, uz pretpostavku o sekulariziranoj kršćanskoj teologiji, stavljanje čovjeka na mjesto Boga kao subjekta u povijesti, odnosno, s druge strane, u predodžbi o novonastalome emancipacijskom samopotvrđivanju čovjeka potaknuti ideju o moderni uopće, kao novome dobu ili etapi čovječanstva. Sociologija i religiologija najprije će u kontekstu modernizacije, industrijalizacije, urbanizacije i tehnologizacije prepoznati sekularizaciju kao svojevrstan gubitak religioznoga temelja društva, kao gubitak smislenosti
} 
svoje strane i teologija daje značajan prinos proširenju značenja samoga pojma sekularizacije, od njezina sve češćega shvaćanja u kulturološkome smislu, kao emancipaciju društva i pojedinaca od utjecaja Crkve i religije, a zatim, u izravnijim i sustavnijim teologizacijama ona postaje, slično kao i u filozofiju, hermeneutička kategorija za shvaćanje odnosa između kršćanstva i svijeta, odnosno vjere i svijeta, a samim time i suvremeni locus theologicus, tj. polazište i perspektiva teološkoga promišljanja sadržaja i prakse vjere, osobito u njezinoj društvenoj i kulturalnoj dimenzionalnosti. Osim spomenutih suglasja većine znanstvenih pristupa u dvostrukome terminološkom shvaćanju pojma sekularizacije - od pravnoga do kulturološkoga - dvije su podudarnosti također zanimljive, a obje su važne za pobliže teološko tretiranje sekularizacijske problematike. Najprije, sekularizacija se (najranije prema E. Troeltschu) shvaća kao dvoznačna pojava u odnosu na kršćanstvo:

»U tom, kulturološkom smislu izraz 'sekularizacija' izražava i proces oslobađanja suvremenog svijeta od skrbništva kršćanstva i Crkve (naglašen diskontinuitet), ali upućuje nas i na prilog koji je kršćanstvo dalo oblikovanju suvremenoga svijeta te na ostatak kršćanskih poticaja u suvremenom društvu (naglašen kontinuitet). (53 $^{53}$

I zatim, ona se značajno razvija u kontekstu filozofijske i teologijske kritike religije, što će također za posljedicu imati problem socio-religiologijskoga određenja pojma religije. ${ }^{54}$ Negdje na razvojnome putu od prihvaćanja sekularizacijskih procesa kao započetih u samome kršćanstvu i u svijetu, odnosno u društvu, koje nije neko idealno zamišljeno kršćansko društvo, preko razlikovanja vjere i religije u naglašenoj kritici religije, do pojedinačnih konkretizacija teoretskih razrada koje uvažavaju sekularizaciju kao imanentni locus theologicus, po prilici se i odvija kršćanska teologija sekularizacije kao eminentno teološki prinos uvažavanju ovoga fenomena i cjelokupne povezane problematike. Dakako da ovdje možemo $s$ tim u vezi skicirati samo značajnije obrise. ${ }^{55}$

općenito, ali u izravnoj vezi sa slabljenjem religije i njezinih pretpostavljenih funkcija za društvo i pojedinca. Najviše će zatim doprinositi fenomenologijskome i empirijskome istraživanju uzroka i učinaka sekularizacijskih procesa u modernome društvu, promišljajući također o posljedicama za tradicionalne i doskora nove religije, nove oblike religioznosti i duhovnosti. Višeznačnost i složenost sekularizacijskih procesa u tom će se znanstvenom kontekstu odraziti i na pojavu novih znanstvenih disciplina, poput psihologije religije.

${ }^{53}$ R. GIBELLINI, Teologija XX. stoljeća, Zagreb, 1999, 121.

${ }^{54}{ }$ Osim već spomenutih unutrašnjih razloga neuspjeha određenja pojma religije, postoje još izvanjski, a otkrivaju se u stalnoj i nepopustljivoj teologijskoj kritici religije. U katolicizmu su sve do Drugoga vatikanskog koncila i njegove deklaracije Nostra aetate nekršćanske religije bile prikazivane i shvaćane više ili manje kao magijske tvorbe ili obična praznovjerja, a u moralnoj teologiji kao posljedice djelovanja zlih sila « (Jukić, Lica i maske svetoga..., 26).

${ }^{55}$ Opsežniji prikaz relevantne teološke literature v.: Gibellini, Teologija XX. stoljeća..., 544548; usp. također: I. RAGUŽ, Poslanje Crkve u pluralizmu - "preobražavajuće prihvaćanje«, Bogoslovska smotra, 73 (2003) 2-3, 270 bilj. 1; 271 bilj. 2. 
Sekularizacija nastaje na kršćanskome kulturalnom prostoru i u samome kršćanstvu i stoga bi bilo iluzorno misliti da bi ono, odnosno kršćanske Crkve i njihova teologija, takvom pojavom, bez obzira na njezinu složenost, bili posve zatečeni i bez osjećaja za realnost društveno-religioznih promjena koje su s tim u vezi.

Teološko promišljanje moderniteta i sekularizacijskih procesa koji su u tom širokom kontekstu izrazito prepoznatljivi u odnosu prema kršćanstvu, shvaćenome i kao religiji, nalazi se, čini se, na samome početku teoloških promišljanja sekularizacijske problematike i u središte postavlja pitanje ne samo odnosa kršćanstva sa suvremenim svijetom, nego i pitanje o kršćanstvu kao religiji. Nakon što je na području filozofijskih i sociologijskih teoretizacija ozbiljno doveden u pitanje funkcionalni smisao religije za modernoga čovjeka i društvo koje oblikuje i uređuje - a sekularizacija upravo to najprije i stavlja u žarište problematike, kako je očito i samim pojmovnim razlikovanjem i suprotstavljanjem saeculum-religio ${ }^{56}$ - kršćanski teolozi započinju promišljati i odnos kršćanstva i svijeta i odnos kršćanstva i religije. Time ne čine ništa samo izvanjski ovisno o pojavi sekularizacije, kojom bi kršćanstvo bilo zatečeno ili na neki način prevladano, nego preispituju vlastite evanđeoske izvore. ${ }^{57}$

Među prvima, teološki o modernome dobu promišlja evangelički teolog D. Bonhoeffer, a u njegovim je shvaćanjima podjednako istaknuta kritika religije i svjetovnost svijeta, što je oboje važan prinos teološkom uvažavanju sekularizacijskih promjena u modernome društvu. Sekularizacija se izravno tematizira u njegovim razmišljanjima, iako će češće, upravo pod vidom kritike religije i potrebe uvažavanja svjetovnosti svijeta, pojmovno to obuhvatiti ideja o »nereligioznom kršćanstvu u punoljetnom svijetu« ${ }^{58}$ Novi oblik nereligioznog kršćanstva odredit će u negativnom i pozitivnom smislu: u negativnom, nereligiozno kršćanstvo je ono, koje znači oproštaj od religije, ali za potvrdu takve tvrdnje, Bonhoeffer nastoji odgovoriti na pitanje o tome, što je zapravo religija. Ako je religiju moguće odrediti kroz tri osnovna elementa - metafizika, untrašnjost $i$ subjektivnost, djelomičnost - slijedi zaključak:

\footnotetext{
${ }^{56}$ Usp. C. DOTOLO, Sekularizam / Sekularizacija, ETR, 1019.

${ }^{57}$ Dovoljno je zapitati se o odnosu Isusa Krista prema svijetu i religiji. Ako bismo, primjerice, starozavjetno farizejstvo pokušali poimati u suvremenome shvaćanju religije [koje kao općeprihvaćeno ipak ne postoji, bez obzira na dva prevladavaljuća pokušaja, tzv. »supstancijalistički« i tzv. »funkcionalistički« (usp. Črpić, Curković Nimac, Tanjić, Vjersko uvjerenje $i$ moralno ponašanje..., $95 \mathrm{slj}$.)], onda bismo mnoga novozavjetna mjesta mogli iščitavati u svjetlu kritike religije kao ljudske uspostave odnosa s Bogom, neovisno o Božjoj inicijativi. Isusov odnos prema svijetu također je izvorna kršćanska potvrda autonomije svijeta, iako ne bez transcendentalne otvorenosti. Zapravo, oboje se u osobi i životu Isusa Krista nalazi u najdubljoj povezanosti, jer religija, koju nalazi zaprjekom istinskome odnosu s Bogom, stoji u znaku osude i odbacivanja svijeta.

${ }^{58}$ Usp. D. BONHOEFFER, Otpor i predanje. Pisma iz zatvora, Zagreb, 1974, 123 slj.; usp. također: J. JUKIĆ, Od nereligioznog do ateističkog kršćanstva, Crkva u svijetu, 14 (1979) 2, 111-118.
} 
»(Prema Bonhoefferu) religija je, dakle, iza svijeta, preskače svijet i povijest; ona je individualizam koji se protivi društvenosti i zajedništvu, naposljetku, religija je djelomična stvarnost te se kao takva protivi cjelovitosti života. ${ }^{59}$

Teološke konsekvencije ovoga jesu potreba za novim hermeneutičkim kriterijem, kao nereligiozno tumačenje biblijskih pojmova ili takvo tumačenje također teoloških pojmova, odnosno i njihovo »svjetovno tumačenje ${ }^{60}{ }^{60} \mathrm{U}$ jednome od svojih pisama Bonhoeffer spominje »život u svijetu etsi Deus non daretur«, što nije ništa drugo nego kritika religijske predodžbe o Bogu, koja je pogrešna, jer taj paradoks »života s Bogom bez Boga« znači u novonastalim okolnostima moderne »živjeti s Bogom objave i s Bogom Isusa Krista, bez 'Boga' religije«, koji se, sukladno tome, shvaća kao prinos kršćanstva kraju one religije, čiji je 'Bog' za nju »deus ex machina«. ${ }^{61}$

Daljnji razvoj teoloških razrada problematike sekularizacije R. Gibellini sažima na sljedeći način:

»Evangelički teolog Friedrich Gogarten prvi na početku pedesetih sekularizaciju, koja je obilježila naše vrijeme, čini temom teologije, a u šezdesetim katolički teolog Johann Baptist Metz preuzima i prevladava 'postavku o sekularizaciji' najprije u ozračju svoje 'teologije svijeta', a zatim u ozračju 'političke teologije'..162

Za Gogartena se doista može reći kako je sekularizaciju učinio važnom i aktualnom temom teologije. Pozivajući se na Heideggera, koji govori o tome da autentičnoga mislioca pokreće jedna jedina temeljna misao, Giorgio Penzo tvrdi: „Što se tiče Gogartena, lako uočavamo da tu temeljnu misao tvori upravo problematika sekularizacije. ${ }^{63} \mathrm{Uz}$ ime ovoga teologa veže se i jedna od mnogih u novije vrijeme nastalih tzv. "genitivnih teologija«, što se, prema Gibelliniju, ipak ne čini s dovoljno opravdanja:

»Gogarten nikad ne govori o 'teologiji sekularizacije', nego umjerenije, kao što glasi podnaslov njegova djela, o 'sekularizaciji kao temi teologije'. U šezdesetim godinama, naprotiv, buknula je rasprava o sekularizaciji i olako se govori o 'teologiji sekularizacije'. « ${ }^{64}$

Novost Gogartenova shvaćanja sekularizacije stoji prvenstveno u njezinu pozitivnom određenju, ${ }^{65}$ iako će tijekom vremena postaviti razliku između »sekularizacije« (Säkularisierung) i »sekularizma« (Säkularismus) kao općenito prihvaćenu u znanstvenoj terminologiji. Prvim pojmom shvaća sekularizaciju

\footnotetext{
${ }^{59}$ Gibellini, Teologija XX. stoljeća..., 116.

${ }^{60}$ Usp. isto, 117.

${ }^{61}$ Usp. isto, 118; Dotolo, Sekularizam / Sekularizacija..., 1019.

${ }^{62}$ Gibellini, Teologija XX. stoljeća..., 122.

${ }^{63}$ G. PENZO, Friedrich Gogarten, Zagreb, 2016, 42.

${ }^{64}$ Gibellini, Teologija XX. stoljeća..., 136.

${ }^{65}$ To ipak, primjećuje Penzo, nije bio slučaj od početka, jer je u svojim spisima do 1937. godine o sekularizaciji pisao kao o negativnoj pojavi, a takvo rašireno tumačenje u teologiji svojega vremena napušta od 1948. godine: »Sekularizaciju ne promatra više samo kao gubitak svetoga, već kao pročišćenje svetoga « (Penzo, Friedrich Gogarten..., 9, bilj. 3).
} 
svijeta kao svjetovnost svijeta, što ne predstavlja više od procesa koji proizlazi iz same kršćanske vjere. Krivo shvaćanje svjetovnosti, izopačenje sekularizacije, koje znači zatvorenost transcendenciji u vidu soteriološke autonomije predstavlja ne tek svjetovnost svijeta, nego i svjetovnost same vjere. Ukratko, dvije su osnovne postavke kojima sekularizacija postaje teološkom temom kod Gogartena: prva, o ne samo negativnom, nego i o pozitivnom značenju sekularizacije, kao pročišćenju svetoga, i druga, o izvorištu čovjekove emancipacije i svjetovnosti svijeta nigdje drugdje, nego u samoj kršćanskoj vjeri. ${ }^{66}$

Ovi uvidi Gogartenova promišljanja sekularizacije kao teme kršćanske teologije trebaju, dakako, biti shvaćeni u unutarnjoj vezi s njegovim osnovnim razumijevanjem kršćanske vjere, koje se može odrediti uvažavanjem triju izrazito teoloških pretpostavki: o kršćanskoj vjeri kao vjeri opravdanja, o kršćanskoj vjeri da je svijet Božje stvorenje kao ishodištu sekularizacije svijeta i čovjekove autonomije u odnosu prema svijetu te konačno, o shvaćanju kršćanske vjere prema kojoj čovjek s Bogom živi u odnosu sinovstva, odakle proizlazi i njegova odgovornost za svijet. ${ }^{67}$ Od Gogartena nadalje u teologiji se, iako ne u potpunome suglasju ${ }^{68}$ nerijetko prihvaća pretpostavka o utemeljenju sekularizacije $u$ biti kršćanske vjere, to jest, o sekularizaciji kao naravnoj posljedici kršćanske vjere, ili barem o kršćanskim izvorima sekularizacijskih procesa, kako on to prvenstveno zastupa i nastoji obrazložiti. ${ }^{69}$

Pozitivno određenje sekularizacije i ovdje se, međutim, polazišno određuje ovisno o već spomenutoj kritici religije kao pokušaju suvremenijega razumijevanja onoga što bi bila autentična kršćanska vjera i njoj odgovarajuće kršćanstvo kao kulturalna i društvena pojava. ${ }^{70} \mathrm{No}$, to se, prema sljedećim riječima G. Penza u Gogartena ne događa međusobnim isključivanjem vjere i religije, nego njihovim razlikovanjem i povezivanjem kroz kategoriju svetoga:

»U vezi s tim moguće je pokazati da se razlikovanje vjere i religije ne može shvaćati kao oprječnost zbog jednostavne činjenice da su vjera i religija izrazi jedne izvornije stvarnosti, a to je upravo sveto, odnosno božansko. Zbog toga aspekta na temeljnoj razini radije treba govoriti o razlikovanju na području

\footnotetext{
${ }^{66}$ Usp. Penzo, Friedrich Gogarten..., 10 slj.

${ }^{67}$ Usp. Gibellini, Teologija XX. stoljeća..., 128-131.

${ }^{68}$ Gibellini ističe kako se u teološkoj raspravi o sekularizaciji, koja se razbuktala u šezdesetim godinama prošloga stoljeća, svi sudionici rasprave nužno pozivaju na Gogartenovu postavku o sekularizaciji, ali to ne znači da je ona općeprihvaćena, nego štoviše, kako to na istaknutim primjerima analizira W. Pannenberg, postoje i bitno različiti zaključci od onih Gogartenovih, u čemu se posebno ističu teolog Romano Guardini i filozof Hans Blumenberg (usp. Gibellini, Teologija XX. stoljeća..., 134 slj.).

${ }^{69}$ Usp. F. GOGARTEN, Verhängnis und Hoffnung der Neuzeit. Die Säkularisierung als theologisches Problem, Stuttgart, 1953, 139-141.

${ }^{70} \mathrm{O}$ potonjemu će ipak, čini se, puno više računa povesti Metzova »teologija svijeta«, a onda još više, njegova »politička teologija«, što i jest razumljivo s obzirom na teološke nijanse u preferiranju individualnoga i društvenoga na području dviju kršćanskih teologija, koje se usporedno bave ovom problematikom. Više o tome v.: G. COCCOLINI, Johann Baptist Metz, Zagreb, 2013.
} 
božanskoga. Religija izražava neautentičnost dimenzije božanskoga, dok vjera tvori autentičnu dimenziju božanskoga općenito, te kršćanskoga božanskoga u određenijem smislu. « $^{71}$

U katoličkoj teologiji, koja je ozbiljno zaokupljena problematikom moderniteta i sekularizacije, nezaobilazno je ime Johanna Baptista Metza. ${ }^{72}$ On će u katoličkom znanstveno-teološkom kontekstu prednjačiti u pozitivnom vrednovanju sekularizacije, ali to će biti moguće impozantnim teološkim razvojem od tzv. »teologije svijeta « do njegova nacrta tzv. »političke teologije «. ${ }^{73}$ Za razliku od Gogartenovih teoloških polazišta u lutherovskome razlikovanju Zakona i evanđelja, Metz svoju postavku o svjetovnosti svijeta utemeljuje kristološki u događaju utjelovljenja:

»U događaju utjelovljenja svijet je prihvaćen kao svijet te je time kao svijet postao autonoman, kao svjetski svijet u nastajanju, kao povijest, kao polje odgovornoga čovjekova djelovanja: 'Upravo u svjetlu poruke da je Bog postao čovjekom, svijet gubi svoje božanstvo koje ga idolatrijski pokriva te, kao u početku, biva predan čovjeku na upravljanje i odgovornost, te tako biva oslobođen u vlastitoj svjetovnosti'. ${ }^{74}$

Metz razlikuje »posvjetovnjenje« ili »mundanizaciju« ${ }^{75}$ kao filozofijsko-kulturalni aspekt povijesnoga tijeka, a sekularizacijom shvaća društveno-političko obilježje toga tijeka. Takvo razlikovanje također je posljedica teoloških postavki razvijenih kod Metza u kristološkom, antropološkom i političko-eshatološkom ozračju promišljanja. Prihvaćanje Gogartenove postavke o sekularizaciji i potrebu njezina prevladavanja Metz obrazlaže opasnošću kod strogoga razlikovanja vjere, kao područja spasenja, od svijeta, kao područja čovjekova djelovanja, čime ponovno može biti riječi o nekome nesvjetskome shvaćanju vjere, a to onda izaziva ozbiljne posljedice za gubljenje javne i društvene dimenzije kr-

\footnotetext{
${ }^{71}$ Penzo, Friedrich Gogarten..., 91.

${ }^{72}$ Dakako, nezaobilazni su u pogledu važnosti i drugi znameniti teolozi koji dolaze s područja katoličke teologije, poput K. Rahnera, M.-Dominique Chenua, J. Daniéloua i H. Urs von Balthasara. No upravo će istraživanja i promišljanja ovih teologa pokazati nejedinstveno, štoviše, vrlo različito poimanje sekularizacijskoga fenomena u vezi s kršćanstvom. Za razliku od prve dvojice, koji uvažavajući sekularizacijske procese u svijetu, predviđaju kršćanstvu »stanje dijaspore « (Rahner) ili neizbježnost odustajanja od kršćanskoga društva kao vanjskoga okvira i potencijalnih sredstava za evangelizaciju (Chenu), Daniélou dopušta kristijanizaciju cjelokupnoga društva, iako ne više u konfesionalnoj državi, nego u ozračju laičkoga života koje podrazumijeva slobodu vjere, dočim se kod Balthasara pozitivan vid sekularizacije u potpunosti odbacuje tvrdnjom da biblijski pojam Boga nije odgovoran za tijek sekularizacije i da se taj tijek ne može pozitivno vrednovati, kao da bi tobože pružao nove mogućnosti kršćanskoj vjeri (usp. Gibellini, Teologija XX. stoljeća..., 144-147). Slično se prema »neopravdanosti sekularizacije» određuje već ranije i R. Guardini (usp. R. GUARDINI, Konac novoga vijeka, Split, 2002).

${ }^{73}$ Usp. J. B. METZ, Zur Theologie der Welt, Mainz-München, 1968; Politička teologija 1967-1997, Zagreb, 2004; Memoria passionis. Provokativni spomen u pluralističkom društvu, Zagreb, 2009.

${ }^{74}$ Usp. J. B. METZ, Sulla teologia del mondo, Brescia, 1969, 63 (cit. prema: Gibellini, Teologija XX. stoljeća..., 148).

${ }^{75}$ Usp. Dotolo, Sekularizam / Sekularizacija, ETR, 1020.
} 
šćanske vjere. Drugu opasnost vidi u nekritičkome shvaćanju sekularizacije kao postupnoga pretvaranja kršćanskih vrednota u svjetovne, čime se izjednačuju sekularizacija i sekularizam i nastaje potpuna sekularizacija. Zato je, prema Metzu, upravo

»nužno ići dalje od 'postavke o sekularizaciji', te je kritički uvrstiti u 'političku teologiju', koja će nadići apstraktnost postavke o sekularizaciji, izbjeći suprotne opasnosti i izobličenja (kakvo je bilo, primjerice, 'teologija Božje smrti'), te znati posredovati između vjere i sekularizacije, između kršćanstva i suvremenoga doba. $\ll^{76}$

Ovdje se ne zaustavlja Metzovo teološko promišljanje o autentičnome kršćanstvu postmoderne kulture pluralizma. Usvajajući i prevladavajući Gogartenovu postavku o sekularizaciji, ono u čemu još uvijek stoji podudarnost dvojice teologa dviju kršćanskih provenijencija, i što bi se moglo sažeto istaknuti kao značajan doprinos većine teoloških napora u kojima se sekularizacija prihvaća kao aktualan povijesni locus theologicus, jest razlikovanje onoga što je u kršćanstvu temeljno, kao otajstveni odnos s božanskom stvarnošću posredovanjem svetoga, bez obzira hoće li se ono više vidjeti u objavljenoj Božjoj riječi ili uosobljenoj Božjoj Riječi. To osnovno kršćanske vjere istinski je sveto koje traže svi oni koji pristaju uz evanđeosku poruku spasenja i pomirenja. Ako to pristaju prihvaćajući kršćanstvo i kao religiju, to u prvome redu od kršćanstva zahtijeva poštivanje autonomije svijeta, što bi i imao značiti pozitivan vid sekularizacije, ali pri tom ne uz prešutno odobravanje različitih oblika ili pojava kojima se zahtijeva apsolutna neovisnost i ravnodušnost s obzirom na transcendenciju. $\mathrm{O}$ tome će Metz promišljati kao o univerzalnome zahtjevu kršćanskoga poslanja u vremenima globalizacije, želeći

"podastrijeti jedan prijedlog kako se teologija 'lica okrenuta prema svijetu' (kako se, dakle, jedna pravo shvaćena 'Politička teologija') može ofenzivno ophoditi s tom novom situacijom, a da ne napusti uvjerenje kako kršćanstvo također i upravo danas ima nešto reći svim ljudima (dakle, 'svijetu') «. ${ }^{77}$

$\mathrm{Na}$ kraju valja barem kratko podsjetiti i na drugu, bez sumnje, značajnu ovjeru sekularizacije, koliko god je pretjerano misliti da i danas, primjerice, u Katoličkoj crkvi svi o tome misle isto. Kod toga se čini uputnim odmah primijetiti da je, od početka naročito teološki promišljane teme o sekularizaciji, ${ }^{78}$ pitanje o kritici religije i stoga odnosu kršćanstva i religije predstavljalo značajno problemsko mjesto, slično kao što je to i pitanje odnosa kršćanstva i svijeta, odnosno vjere i svijeta. Prvo od tih pitanja, iako ne gubi potpuno na svojoj aktualnosti, ipak je, danas, manje relevantno za ono drugo pitanje, zbog kojega se

\footnotetext{
${ }^{76}$ Gibellini, Teologija XX. stoljeća..., 149.

${ }^{77}$ J. B. METZ, Prijedlog univerzalnog programa kršćanstva u doba globalizacije, u: R. GIBELLINI (ur.), Teološke perspektive za XXI. stoljeće, Zagreb, 2006, 395.

78 »Nakon Drugoga svjetskog rata u gotovo svim teološkim raspravama o novovjekovnim mijenama u društvu prevladavao je pojam sekularizacije« (Raguž, Poslanje Crkve u pluralizmu..., 270).
} 
početno zapravo u velikoj ovisnosti i postavlja. Danas je za katoličku teologiju samorazumljivo ustvrditi da je kršćanstvo, unatoč različitim tumačenjima, također i religija. ${ }^{79}$ Pri tom valja voditi računa o tome da niti religijske strukture, niti prolazni kulturalni sastojci vremena, ili možda nešto treće, nisu ono bitno u kršćanstvu, te stoga, strogo uzevši, možda ponekad s nedovoljno jasnoće govorimo o krizi kršćanstva, umjesto o krizi onoga što je s njim - zacijelo i kao s religijom - možda tek u privremenoj i prolaznoj povezanosti. Ili, kako će ustvrditi T. Matulić:

»Kad se u novije vrijeme sa svih strana čuje govoriti o krizi kršćanstva, o radikalnoj dekristijanizaciji čitavih naroda i kultura, poglavito na Zapadu, tada se premalo vodi računa o prije spomenutom suodnosu 'biti dobar čovjek' i 'biti dobar vjernik'. Držimo da uopće nije riječ o krizi kršćanstva, nego isključivo o krizi onoga što se olako nazivalo kršćanstvom, a da s kršćanstvom nije imalo niti ima čvrste nutarnje veze. « ${ }^{80}$

Takvo razmišljanje, za kakvo bismo, na različite načine očitovano, mogli nalaziti mnoge potkrjepe u Mardešićevim tekstovima, itekako nam se čini važno upravo za konstataciju o crkvenoj ovjeri sekularizacije. Prihvaćajući modernitet kao stvarnost, djelomično i kao nužan povijesni, pa i poželjan razvoj u shvaćanju i prihvaćanju općereligioznih i općeljudskih vrednota, povezivih s kršćanskom tradicijom, Crkva je na Drugome vatikanskom koncilu učinila dvije bitne prekretnice: jednu u pozitivnom vrednovanju nekršćanskih religija, ${ }^{81}$ i drugu, uvažavanjem evanđeoski i teološki utemeljene potvrde tzv. »autonomije zemaljskih stvari«, ${ }^{82}$ što je prema Mardešiću posve očito prihvaćanje sekularizacije ne samo kao nepobitne povijesno-procesne stvarnosti, nego i njezina pozitivnoga određenja. ${ }^{83}$ Takvo određenje ne znači odmah zagovaranje niti poželjnost sekularizacije, pogotovo ne zbog stalne opasnosti sekularizma, ne niti šansu za ponovno društveno ili kulturalno, a kamoli državno-pravno osnaženje kršćanstva, nego jednostavno priliku za aktualizaciju temeljnoga poslanja $\mathrm{Cr}$ kve u prihvaćanju svjetovnosti svijeta prema primjeru i milosti utjelovljenoga Sina Božjega. Nema nikakve sumnje da je takvoj povijesno ostvarenoj prilici u

\footnotetext{
${ }^{79}$ Usp. Ž. TANJIĆ, Religija kao »sporno pitanje«. Osvrt na predavanje Edmunda Arensa, Bogoslovska smotra, 78 (2008) 1, 64.

${ }^{80}$ T. MATULIĆ, Željko Mardešić, svjedok zaboravljenoga dijaloga, Nova prisutnost, 9 (2011) 2, 372. Navedeno nije u oprjeci s Mardešićevim riječima: »Unatoč nejednakim tumačenjima na kraju se pokazalo da svi isto vide istinu o teško izlječivoj krizi povijesnoga kršćanstva u naše doba" (Mardešić, Sekularizacija i odgovori vjernika..., 14).

${ }^{81}$ Usp. DRUGI VATIKANSKI KONCIL, Dokumenti (Deklaracija o odnosu kršćanstva prema nekršćanskim religijama), Zagreb, ${ }^{7} 2008,391-399$.

${ }^{82}$ Usp. DRUGI VATIKANSKI KONCIL, Dokumenti (Pastoralna konstitucija o Crkvi u suvremenom svijetu), br. 36, 702.

${ }^{83} \gg$ A valja samo pročitati pet redaka teksta iz konstitucije Radost $i$ nada i uvjeriti se u suprotno. To onda otkriva svu poželjnost sekularizacije i moderniteta koji su u najvećoj mjeri svojim djelovanjem otklanjali, poništavali i čistili upravo ideološke naslage na tijelu povijesnoga kršćanstva« (Mardešić, Sekularizacija i ideologija..., 15); usp. Jukić, Lica i maske svetoga..., 26.
} 
prihvaćanju autonomije svijeta na Drugome vatikanskom koncilu - što ovdje shvaćamo i kao zahtjev kršćanske vjere i kao crkvenu ovjeru sekularizacijskih procesa - velik doprinos dala upravo teologija, kako se dade naslutiti i iz Mardešićeva pitanja:

»Tako su sekularizacija i modernitet dale priliku kršćanstvu da ponovno otkrije svoje izvorno značenje koje je stoljećima bilo zatrpano sporednostima i grešnim strukturama. Nije li konačno upravo teologija bila primorana rastumačiti svjetovnost svijeta mnogo dublje i dalekosežnije od same sociologije? « ${ }^{84}$

Zahvaljujući naporima i teologa i koncilskih otaca, ono što je kod toga osobito važno za sva daljnja promišljanja odnosa kršćanstva i svijeta kao vjere i svijeta, jest sljedeća konstatacija:

»(...) može zvučati iznenađujuće, ali je ipak istinito, da je najrealniju, najuravnoteženiju i utoliko najbolju analizu stanja suvremenoga svijeta, uključujući kulturu i civilizaciju, dala Crkva na Drugom vatikanskom koncilu, i to ponajprije u 'Gaudium et spes' . $^{85}$

Crkva je to, vođena Duhom Svetim, svakako bila u stanju učiniti i zbog svoje teologije, koja se značajno počela zanimati za stvarno stanje suvremenoga svijeta u kojemu Crkva i opstoji. Za one, koji možda i danas u koncilskim pogledima na svijet vide neopravdanu prilagodbu Crkve modernitetu, pa i kroz svojevrsnu crkvenu ovjeru sekularizacije, nalazeći pri tom »krivce« u njezinim teolozima, primjerenim se čini Mardešićeva prognoza aktualnosti teoloških pravaca pozornih prema sekularizacijskoj problematici:

»Njihov se prijepor, znači, može ukratko sažeti u pitanju o tome što valja prvo povlastiti kad se danas želi predstaviti kršćanstvo tražiteljima svetoga: ili isključene i potlačene iz društva kako misli teologija oslobođenja ili pak podržati sva pozitivna i objektivna postignuća u oblasti spoznaje, tehnike i ljudskih prava, kako drži teologija svijeta i teologija kritične slobode. Prva nudi oslobođenje, druga slobodu. Budući da nam jedno i drugo nedostaje, potreba će se njihova glasnog govora pokazivati i dalje neophodnom. « $^{86}$

\section{Umjesto zaključka}

Vanjski društveno-kulturalni procesi pomažu u razumijevanju i znanstvenoj obradi, ali ne proniču u bit unutarnjega života, o kojemu ovise ne samo religiozno uvjerenje, doživljavanje i praksa, nego i moralno-etičke pretpostavke, pojedinačna stajališta, ali i složeni svjetonazorski sustavi, od kojih se neki tijekom vremena s kulturalne i društvene prenose i na temeljnu antropološku

\footnotetext{
${ }^{84}$ Mardešić, Sekularizacija i teologija..., 15.

${ }^{85}$ T. MATULIĆ, Mogućnosti i granice suvremene znanosti, Bogoslovska smotra, 76 (2006) 2, 286.

${ }^{86}$ Mardešić, Crkva i suvremeni svijet..., 918.
} 
razinu životne stvarnosti, odakle se pod krinkom civilizacijskoga dosega predlažu i zagovaraju kao zahtjevi novih načina uređenja i preobrazbe društvenokulturalne zbilje. U analizi sličnih transformacija samih društveno-kulturalnih procesa, koji su vanjski pokazatelj unutarnjih religijskih i religioznih, odnosno duhovnih, moralno-etičkih i svjetonazorskih promjena, donedavno je, istražujući fenomen sekularizacije na našim prostorima, prednjačio Željko Mardešić. Prvenstveno zaslužan za pravovremeno upoznavanje domaće znanstvene javnosti s prinosima aktualnih znanstvenih istraživanja u svijetu, njegova izvorna promišljanja dotične problematike čine se još aktualnijima i polazišno posve uporabljivima u sučeljenju s religiologijski relevantnim unutarnjim i vanjskim procesima, poput sekularizacijskih i onih koji su s ovima u najdubljoj vezi, a koje prepoznajemo kroz različito i sve brojnije nazivlje: antisekularizacija, desekularizacija, revitalizacija religije, religijske preobrazbe, (de)sakralizacija, laicizacija, laičnost, laicitet, pluralizam, relativizam, društvene i antropološke, odnosno socio-biološke, bioetičke i rodne teorije ili ideologije.

Uzmemo li u obzir samo njegovo ukazivanje na dvoznačnost sekularizacijskoga fenomena, prema kojoj je neki prepoznatljiv društveno-kulturalni proces posve istraživ u pogledu različitosti posljedično činjenične stvarnosti, od slabljenja društvene relevantnosti religije do rascvata novih oblika religioznosti ili duhovnosti, od čega je većina protumačiva u skladu s općom teorijom sekularizacije kao društvene relativizacije religioznih uvjerenja i prakse, a na drugoj strani jednako je utvrdiva još i snažnija društvena, pa čak i pravno-politička revitalizacija religijski nipošto indiferentnih sastavnica antropološke zbilje, čini se ne tek poželjnim, nego i nužnim istraživati i aktualizirati njegovu socioreligiologijsku misao upravo u pozornosti prema fenomenu sekularizacije.

Zasigurno bi veći prinos aktualizaciji Mardešićevih istraživanja fenomena sekularizacije bilo izravno tretiranje barem pojedinih religiologijski relevantnih društveno-kulturalnih procesa, koji se izrazitije javljaju u aktualnoj znanstvenoj raspravi i koji, baš poput svojedobno teorije o sekularizaciji, svakodnevno proizlaze iz znanstvenih, ali i ideologijskih radionica ljudske kreativnosti. Ipak, nepreskočivim korakom te aktualizacije čini se upravo razmišljanje o sekularizaciji pod vidom njezinih značajnijih povijesno-znanstvenih ovjera. Ono što se pritom prepoznaje i uvažava kao impresivan prinos Željka Mardešića razumijevanju religije, kršćanstva i povezanih društveno-kulturalnih procesa jesu adekvatna znanstvena istraživanja obogaćena izvornošću intelektualnih i duhovnih uvida.

$\mathrm{Ni}$ tu se, kako i samo tretiranje fenomena sekularizacije pod vidom socioreligiologijske, odnosno društvene i teološko-crkvene ovjere već izdaleka naznačuje, ne iscrpljuje njegova pronicljivost. Za pozitivan vid sekularizacije, najmanje u smislu nepovredivosti znanstvene, objektivne ili neutralne znanstvene teorije, daljnje vrijednosne prosudbe imaju i dalekosežnije značenje. Mardešić je u tom pogledu prvenstveno usredotočen na sveto, kao posredovanje između 
ljudske i božanske zbilje, kao otvorenost kršćanstva u svojoj temeljnoj odrednici, ali i u povijesnim oblicima religijske i religiozne pojavnosti, onoj stvarnosti, koju obično nazivamo transcendencijom. To je zalaganje za istinskim traženjem svetoga kao kršćansko i humano, mirotvorno nastojanje oko postajanja boljim čovjekom radi odgovornosti prema zahtjevu svjedočenja kršćanske vjere u konkretnome društvu i kulturi ljudi današnjice. To je možda i krajnji ishod njegovih znanstvenih istraživanja svetoga, koji je ipak u izravnoj i bitnoj unutarnjoj vezi s istraživanjima i promišljanjima fenomena sekularizacije i moderniteta u obziru prema sadašnjemu povijesnome stanju kršćanstva.

Za razliku od mnogih sličnih istraživanja, u Mardešićevim je stalno uključeno pitanje o tome što je zapravo kršćanstvo, nalazi li se ono u krizi i što je čini, kako se prema tome odnositi i što se može učiniti ne samo gorljivim željama, političkim, društvenim ili kulturalnim funkcijama i mehanizmima, nego prije svega autentičnom vjerom obraćenja i njezinim svjedočenjem. Put do autentične vjere, dakako, neostvariv je bez Božje inicijative. Ono što je znanstvenim metodama dohvatljivo, a Mardešić je najviše istraživao na području društvene religiologije, jesu vanjski uzroci i učinci unutarnje dinamike Božjega dara ili milosti vjere. Iako bi njegov, premalo istraženi teorem »rascjep u svetome« valjalo aktualizirati upravo u pogledu točnijega razumijevanja njegova često posvjedočenoga zalaganja za evanđeosko i koncilsko kršćanstvo, kao jedinu alternativu pojavama katoličkoga integrizma i fundamentalizma pretkoncilskoga i predmodernoga razdoblja, čini se da je u tome moguće vidjeti i jednu od ponajboljih ovjera fenomena sekularizacije, u svoj paradoksalnosti i složenosti sekularizacijskih procesa, zbog čega je sekularizacija i hermeneutički put razumijevanja novijih društveno-kulturalnih pojava, a jednako tako i ispravnijega tumačenja pa i vrednovanja izravnijih pojavnosti u okrilju samoga kršćanstva.

Danas, kada se u okvirima socio-religiologijskih i teologijskih istraživanja sekularizaciju možda ponekad percipira kao nedovoljno obuhvatnu teoriju za tumačenje interakcijski relevantnih pojava i stvarnosti na području društva, kulture, religije, etike, kršćanstva i duhovnosti, obnovljeno zanimanje za fenomen sekularizacije također i u svjetlu spomenutoga Mardešićeva teorema, ne čini se neopravdanim. Prevladavajući govor o laičnosti, o načelu laičnosti i laičkoj državi, zacijelo nije samo stvar terminoloških preferencija u pristupu povijesno različitim, ili čak, prema mišljenju nekih, sličnim pa i istoznačnim procesima. Zanimljive su i konstatacije o ostvarivosti laičke države ovisno o stupnju sekulariziranosti nekoga društva. Na drugoj strani zastupa se stajalište o pluralizmu, nasuprot laičnosti i sekularizaciji, kao nekom već dovršenom društveno-kulturalnom stanju. Sve su to aktualni, relevantni i zanimljivi pristupi na teoretskim i praktičnim razinama ljudskoga znanja i zalaganja, koji nisu bez posljedica za osobno svjedočenje i društveno ozbiljenje kršćanske vjere. 
Utoliko se aktualnost Mardešićevih istraživanja o fenomenu sekularizacije također i u perspektivi njezinih povijesno-znanstvenih ovjera čini ne samo izvjesnom, nego u polazištima prepoznavanja i uvažavanja aktualizacijskih potencijala njegovih promišljanja zapravo i očitom. Za pravno i političko načelo laičnosti kršćanstvo sadrži vrednote laiciteta, to jest laičke, odnosno upravo svjetovne dimenzije konkretnih vlastitosti svoje temeljne stvarnosti, kako na razini institucije, tako i na razini vjerskih uvjerenja i prakse. Te iste, premalo promišljene i društveno aktualizirane vrednote pružaju mogućnost primjerenoga kršćanskog odgovora na postavku o ostvarivosti načela laičnosti prema stupnju sekularizacije nekog društva, što je po sebi, dakako, vrlo upitno gledanje na društveno-politički ideal laičnosti u ovisnosti o zasigurno neostvarivoj sekularizaciji svih segmenata društva. Pluralizam svjetonazora čini se konačnom zbiljom zapadnjačkih društava, ali teško je zamisliv kao već ostvareno stanje, za razliku od vjerojatnije stvarnosti, kao dijelom determiniranih društvenokulturalnih procesa, koji upućuju prema takvome stanju.

Aktualnost Mardešićevih istraživanja, također već u obliku karakterističnih ovjera sekularizacijskih procesa u svijetu u kojemu je današnje kršćanstvo obvezno otvarati puteve prema istinski svetome, zaista je neprevidiva. Sveto je za njega poruka spasenja i potpunoga oslobođenja čovjeka i cjelokupne stvarnosti kojom je obilježen, a mnoge od novijih društveno-kulturalnih pojava, od kojih su neke ovdje spomenute, uvelike su istražive i kao trajno nastajuće posljedice onoga, što Mardešić prepoznaje u dinamici kompleksnoga događanja, zamislivoga i kroz predodžbu o procjepu ili rascjepu u svetome. 


\section{Stjepan Brebrić* \\ Verifications of secularization - the actuality of Mardešićs research \\ Summary}

Scientific verification of secularization in this paper is taken as a general research framework investigating socio-cultural changes relevant in religiology, especially its consequences for Christianity and also within Christianity itself. The way secularization is here considered seems to be adequate for taking into account the polyvalency and complexity of some processes of secularization concerning its hermeneutical validity in due to further analyses and explanations of state and role Christianity and religions take in contemporary societies and in nowadays world. At the same time there is also endeavour to actualize some relevant Željko Mardešić's researches, concerning both the phenomenon of secularization and some of comparable contemporary socio-cultural processes.

Key words: secularization, modernity, verification, sociology of religion, theology, Christianity, religion, faith, ethics, society, world, holy.

(na engl. prev. Stjepan Brebrić)

\footnotetext{
* Stjepan Brebrić, PhD, Director and Editor-in-Chief, Kršćanska sadašnjost; Address: Marulićev trg 14, HR-10000 Zagreb, Croatia; E-mail: ks@zg.t-com.hr.
} 